\title{
Enhanced secondary organic aerosol formation from the photo-oxidation of mixed anthropogenic volatile organic compounds
}

\author{
Junling $\mathrm{Li}^{1}$, Hong $\mathrm{Li}^{1}$, Kun $\mathrm{Li}^{2}$, Yan Chen ${ }^{3}$, Hao Zhang ${ }^{1}$, Xin Zhang ${ }^{1}$, Zhenhai Wu ${ }^{1}$, Yongchun Liu ${ }^{4}$, \\ Xuezhong Wang ${ }^{1}$, Weigang Wang ${ }^{3}$, and Maofa Ge ${ }^{3}$ \\ ${ }^{1}$ State Key Laboratory of Environmental Criteria and Risk Assessment, \\ Chinese Research Academy of Environmental Sciences, Beijing 100012, China \\ ${ }^{2}$ Laboratory of Atmospheric Chemistry, Paul Scherrer Institute, 5232 Villigen, Switzerland \\ ${ }^{3}$ State Key Laboratory for Structural Chemistry of Unstable and Stable Species, Beijing National Laboratory for Molecular \\ Sciences, CAS Research/Education Center for Excellence in Molecular Sciences, Institute of Chemistry, Chinese Academy of \\ Sciences, Beijing 100190, China \\ ${ }^{4}$ Beijing Advanced Innovation Center for Soft Matter Science and Engineering, Beijing University of Chemical Technology, \\ Beijing 100029, China
}

Correspondence: Hong Li (lihong@ craes.org.cn)

Received: 17 November 2020 - Discussion started: 26 November 2020

Revised: 22 April 2021 - Accepted: 25 April 2021 - Published: 21 May 2021

\begin{abstract}
Vehicular exhaust is one of the important contribution sources of secondary organic aerosol (SOA) in urban areas. Long-chain alkanes and aromatic hydrocarbons are included in gaseous organic pollutants of vehicle emissions, representative of diesel and gasoline vehicles respectively. In this work, the SOA production from individual anthropogenic volatile organic compounds (AVOCs) (n-dodecane, 1,3,5-trimethylbenzene) and mixed AVOCs ( $n$-dodecane $+1,3,5$-trimethylbenzene) was studied with a large-scale outdoor smog chamber. Results showed that the SOA formation from the mixed AVOCs was enhanced compared to the predicted SOA mass concentration based on the SOA yield of individual AVOCs. According to the results of mass spectrometry analysis with electrospray ionization time-of-flight mass spectrometry (ESI-ToF-MS), interaction occurred between intermediate products from the two precursors, which could be the main reason for the enhanced SOA production from the mixed AVOC reaction system. The study results could improve our understanding about the contribution of representative precursors from vehicular exhaust to the formation of SOA in urban areas. This study also indicates that further studies on SOA chemistry from the mixed VOC reaction system are needed, as the interactions between them and the effect on SOA formation can give us a further understanding of the SOA formed in the atmosphere.
\end{abstract}

\section{Introduction}

Secondary organic aerosol (SOA) has received considerable attention during the past few decades, as it plays an important role in affecting global climate change (Shrivastava et al., 2017; von Schneidemesser et al., 2015; Mellouki et al., 2015; Kanakidou et al., 2005), atmospheric visibility (R. Zhang et al., 2015; Moise et al., 2015; Laskin et al., 2015; Ren et al., 2018), and public health (Poschl, 2005; Poschl and Shiraiwa, 2015; Zhang et al., 2016; Requia et al., 2018). The formation, growth, and transformation of SOA influence the atmospheric aerosol's physicochemical properties (Poschl and Shiraiwa, 2015; Moise et al., 2015; Mellouki et al., 2015; Herrmann et al., 2015). The precursors of SOA mainly include anthropogenic volatile organic compounds (AVOCs) and biogenic volatile organic compounds (BVOCs) (Kelly et al., 2018); in urban areas, AVOCs are the main sources of SOA, e.g., gasoline vehicle emissions (Johnson et al., 2004; Charron et al., 2019; Yang et al., 2018), diesel vehicle emissions (Paulsen et al., 2005; Wirtz and Martin-Reviejo, 2003; Odum et al., 1996; Zhao et al., 2015), and solvent use (Li et al., 2017c; Kansal, 2009).

Early regional air quality models underestimated the observed SOA concentrations in large areas of the atmosphere (Volkamer et al., 2006; Heald et al., 2005; de Gouw et al., 
2005; Appel et al., 2017; J. Huang et al., 2017); since incorporating the newly discovered SOA sources, the gap between the observed and predicted SOA concentrations has been decreasing (Zhao et al., 2016; Slowik et al., 2010; Hodzic et al., 2010). The SOA formation processes in the atmosphere are very complicated; although the degradation of most VOCs is clear now, the formation and aging of a large amount of SOA is still unclear. Previous studies found that the observed organic aerosol concentration could not be explained by the traditional yields of the measured AVOCs (de Gouw et al., 2005); in addition, field observations found that potential interactions between AVOCs and BVOCs existed during SOA formation (Spracklen et al., 2011; Hoyle et al., 2011; Glasius et al., 2011; Galloway et al., 2011; Kari et al., 2019): AVOCs could enhance (Spracklen et al., 2011; Carlton et al., 2010; Shilling et al., 2013) or suppress SOA formation from BVOCs (Kari et al., 2019). A recent study also found that SOA formation could be reduced by the mixture of BVOCs (McFiggans et al., 2019). These findings indicate that there are interactions in the complex mixtures of VOCs which may influence the SOA production estimation if they are considered in models.

In urban areas, vehicular exhaust is one of the important sources of SOA, the representative substances of which include aromatic hydrocarbons and long-chain alkanes (Paulsen et al., 2005; Wirtz and Martin-Reviejo, 2003; Charron et al., 2019; Saathoff et al., 2009; Zhao et al., 2015; Gentner et al., 2012). As an important contributor to SOA in urban areas, aromatic hydrocarbons are generally concerned about their kinetics (Atkinson and Arey, 2003; Calvert et al., 2002), reaction mechanisms (Tsiligiannis et al., 2019; Midey et al., 2003; M. Huang et al., 2017b; Wang et al., 2020; Garmash et al., 2019), SOA yield (Cao and Jang, 2007; Kroll et al., 2007; Ng et al., 2007b; M. Huang et al., 2017a), ozone generation potential (Luo et al., 2019), and SOA physicochemical properties (optical properties, morphology, etc.) (Grosjean, 1981; K. Li et al., 2018, 2017; Phillips and Smith, 2014; Kim and Paulson, 2013; Huang et al., 2018). Longchain alkanes, as representative substances of intermediate volatile organic compounds (IVOCs), are considered a potential contributor of SOA (Robinson et al., 2007; Trostl et al., 2016; Shiraiwa et al., 2013). Studies about long-chain alkanes include SOA chemical composition (Fahnestock et al., 2015; Yee et al., 2013; Aimanant and Ziemann, 2013; Yee et al., 2012), SOA yield (Loza et al., 2014; Tkacik et al., 2012), and SOA optical properties (J. Li et al., 2017a, 2020). Aromatic hydrocarbons and long-chain alkanes are generally studied separately in the laboratory. However, it should be noted that in the real atmosphere, aromatic hydrocarbons and long-chain alkanes often exist at the same time, especially from vehicle emissions ( $\mathrm{Wu}$ and $\mathrm{Xie}, 2018$ ). The studies that cover these two types of substances in one reaction system are still limited, and the corresponding SOA formation and reaction processes are not yet clear.
In this work, 1,3,5-trimethylbenzene and $n$-dodecane are selected as representative substances. As the concentration of 1,3,5-TMB is much higher than that of $n$-dodecane in both the gasoline compositions and ambient air, the initial concentration ratio of $1,3,5-\mathrm{TMB}$ and $n$-dodecane in this work is about 10:1 (ppbv). Schauer et al. (2002) reported that 1,3,5-TMB and $n$-dodecane in the gasoline composition were about 7450 and $136 \mu \mathrm{g} \mathrm{g}^{-1}$, respectively; Gentner et al. (2012) reported that the weight percentages of 1,3,5TMB and $n$-dodecane in liquid gasoline were $0.530-0.881$ and $0.004-0.045$ (\% weight by carbon), respectively. According to field observations in China, the measured 1,3,5TMB concentration at the rural site in the YelRD (Yellow River Delta) region in 2017 could reach $1.447 \mathrm{ppb}$ (Chen et al., 2020), and the measured $\mathrm{C}_{12}$ alkane concentration was $0.122 \pm 0.12 \mathrm{ppb}$ in the PRD (Pearl River Delta) region and $0.129 \pm 0.086 \mathrm{ppb}$ in the NCP (North China Plain) region in 2018 (Wang et al., 2020).

This work aims to investigate the SOA formation from the mixed AVOC reaction system. In this study, the SOA yield derived from $n$-dodecane and 1,3,5-trimethylbenzene in the presence of HONO was obtained in a large-scale outdoor smog chamber, and the SOA derived from the mixed AVOCs was measured. The measured SOA mass concentration from the mixed AVOC reaction system was compared to the predicted SOA mass based on the SOA yield of $n$ dodecane and 1,3,5-trimethylbenzene. SOA particles were collected and analyzed with electrospray ionization time-offlight mass spectrometry (ESI-ToF-MS) to achieve insight into the chemical composition and interactions. The results here are helpful to improve our understanding of the contribution of representative precursors from vehicle exhaust to SOA.

\section{Experimental section}

\subsection{Experimental methods}

The experiments were conducted in a $56 \mathrm{~m}^{3}$ $(3.2 \mathrm{~m} \times 6.2 \mathrm{~m} \times 2.5 \mathrm{~m})$ outdoor smog chamber constructed at the Chinese Research Academy of Environmental Sciences (the CRAES chamber; $40^{\circ} 02^{\prime} 27.73^{\prime \prime} \mathrm{N}$, $\left.116^{\circ} 24^{\prime} 41.56^{\prime \prime} \mathrm{E}\right)$. Details of the chamber have been described previously (Li et al., 2021). Briefly, the chamber was made of FEP Teflon film, the light transmission of which was above $90 \%$ at the wavelength of $350-900 \mathrm{~nm}$. The substances inside the chamber could be mixed well within $4 \mathrm{~min}$. The experimental duration under solar irradiation was about $7-8 \mathrm{~h}$. After each experiment, the chamber was cleaned with zero air for at least $24 \mathrm{~h}$ with a flow rate of $200 \mathrm{~L} \mathrm{~min}^{-1}$.

1,3,5-trimethylbenzene or $n$-dodecane was introduced into the chamber by zero air through the custom-made Ushaped glass tube with a known volume of liquid 1,3,5- 
trimethylbenzene or $n$-dodecane. Concentrations of $1,3,5-$ trimethylbenzene and $n$-dodecane were measured before and after reactions by collecting samples on Tenax TA solid adsorbent and analyzing by thermal desorption-gas chromatography with flame ionization detection (TD, UNITY-xr; GC, 7890B). The $\mathrm{OH}$ precursor of the experiments was HONO; it was prepared by dropwise addition of $1 \mathrm{~mL} 2 \mathrm{wt} \% \mathrm{NaNO}_{2}$ solution into $2 \mathrm{~mL} 15 \mathrm{wt} \%$ sulfuric acid solution in a custommade glass bubbler, the bubbler was attached to the smog chamber with a Teflon tube, and the formed HONO was introduced into the chamber by zero air. The $\mathrm{NO}$ and $\mathrm{NO}_{2}$ and formed ozone in the chamber were measured by an $\mathrm{NO}_{x}$ analyzer (EC9841, ECOTECH, Australia) and an ozone analyzer (EC9830, ECOTECH, Australia), respectively. After the gas species mixed evenly in the chamber, the enclosure of the chamber was opened.

After each photochemical experiment, the formed aerosol particles in the chamber were collected by a low-flow sampler (LV 40BW, Sibata Scientific Technology Ltd., Soka, Japan) at a flow rate of $5 \mathrm{~L} \mathrm{~min}^{-1}$ for $10 \mathrm{~min}$. The PTFE filters $(0.2 \mu \mathrm{m}, 47 \mathrm{~mm}$, Merck Millipore, type FGLP) used were extracted in $5 \mathrm{~mL}$ methanol sonicating for $30 \mathrm{~min}$. The methanol solutions were analyzed with ESI-TOF-MS (Bruker, Impact II) in positive mode, and the chemical compositions of the formed SOA were obtained. The methanol solutions were also detected with a UV-Vis light spectrometer (Hitachi, U-3900), which was used to detect the absorbing property of the formed SOA. The attenuated total internal reflection infrared (ATR-IR) analysis was applied to determine the potential functional groups in SOA extracts; an FTIR spectrometer (Bruker, Tensor 27) equipped with a RT-DLaTGs detector was used. The SOA extracts were deposited and dried directly on the Diamant crystal of an ATRIR cell. The spectra of the dry SOA extracts were recorded using a background spectrum obtained with no samples as the reference (100 scans, $2.4 \mathrm{~cm}^{-1}$ resolution).

The following chemicals were used without further purification: 1,3,5-trimethylbenzene (1,3,5-TMB) (99\%, Acros), $n$-dodecane (> 99\%, Alfa Aesar), sulfuric acid (>95\%, Beijing Chemical Works), sodium nitrite ( $98 \%$, Alfa Aesar), methanol (99.9\%, Merck), and acetonitrile $(99.8 \%$, Fisher Chemical).

\subsection{Calculation methods}

\subsubsection{Wall-loss corrections}

As SOA yields could be underestimated due to the losses of SOA forming vapors to chamber walls, the vapor wall loss was considered and corrected in this work (Zhang et al., 2014). The competition between the uptake of organic vapor by the chamber walls and the aerosol particles would determine the effect of vapor wall loss on SOA yields (X. Zhang et al., 2015). The ratio of average gas-particle partitioning timescale $\left(\bar{\tau}_{\mathrm{g}-\mathrm{p}}\right)$ to the vapor wall-loss timescale $\left(\bar{\tau}_{\mathrm{g}-\mathrm{w}}\right)$ could be used to evaluate the underestimation of SOA yields (Zhou et al., 2011; Chen et al., 2019).

The average gas-particle partitioning timescale $\left(\bar{\tau}_{\mathrm{g}-\mathrm{p}}\right)$ could be expressed as the following equation (Seinfeld and Pandis, 2016; Zhang et al., 2014):

$\bar{\tau}_{\mathrm{g}-\mathrm{p}}=\frac{1}{2 \pi \bar{N}_{\mathrm{p}} \bar{D}_{\mathrm{p}} D_{\mathrm{gas}} \bar{F}_{\mathrm{FS}}}$,

where $\bar{N}_{\mathrm{p}}$ was the average number concentration of the formed particles during the experiment, $\bar{D}_{\mathrm{p}}$ was the number mean diameter of the particles, $D_{\text {gas }}$ was the gas-phase diffusivity, and $\bar{F}_{\mathrm{FS}}$ was the Fuchs-Sutugin correction for noncontinuum mass transfer (Seinfeld and Pandis, 2016).

The vapor wall-loss timescale $\left(\bar{\tau}_{\mathrm{g}-\mathrm{w}}\right)$ could be expressed as the following equation (X. Zhang et al., 2015):

$$
\begin{aligned}
& \bar{\tau}_{\mathrm{g}-\mathrm{w}}=\frac{1}{k_{\mathrm{w}}} \\
& k_{\mathrm{w}}=\left(\frac{A}{V}\right) \frac{a_{\mathrm{w}} \frac{\bar{c}}{4}}{1.0+\frac{\pi}{2}\left[\frac{a_{\mathrm{w}} \bar{c}}{4\left(k_{\mathrm{e}} D_{\mathrm{gas}}\right)^{0.5}}\right]},
\end{aligned}
$$

where $k_{\mathrm{w}}$ was the wall loss rates of the organic vapor; $\frac{A}{V}$ was the ratio of surface to volume of the chamber, $1.55 \mathrm{~m}^{-1}$ for this chamber; $a_{\mathrm{w}}$ was the mass accommodation coefficient of vapors deposition to the wall $\left(10^{-5}\right.$ was used here) (Zhang et al., 2014); $\bar{c}$ was the root mean square speed of the gas; and $k_{\mathrm{e}}$ was the eddy diffusion coefficient, which was set to $0.12 \mathrm{~s}^{-1}$ according to the reported values for a $60 \mathrm{~m}^{3}$ chamber (McMurry and Grosjean, 1985). Detailed calculation of $\bar{c}, D_{\text {gas }}$, $k_{\mathrm{n}}$, and $\bar{F}_{\mathrm{FS}}$ is shown in the Supplement. The uncertainty of the mass correction here is about $\pm 11.2 \%$ (see Supplement for details).

Particle wall loss to chamber walls would also cause underestimation when calculating the SOA yield from measurements if these losses were not corrected for. Thus particle wall loss was accounted for during the experiments. The particle growth data were corrected for wall loss, in which sizedependent coefficients from inert particle wall-loss experiments (ammonium sulfate) were applied to the particle volume data (Li et al., 2021):

$k_{\text {dep }}(d)=6.35 \times 10^{-6} d^{1.56}+\frac{6.38}{d^{0.67}}$,

where $k_{\text {dep }}(d)$ was the wall-loss coefficient of particles in the diameter $d$.

\subsubsection{SOA yields}

The secondary organic aerosol (SOA) yield $(Y)$ was defined as the fraction of a reactive organic gas (ROG) that was converted to aerosols, and it could be calculated by the following equation:

$$
Y=\frac{\Delta M_{\mathrm{o}}}{\Delta \mathrm{ROG}}
$$




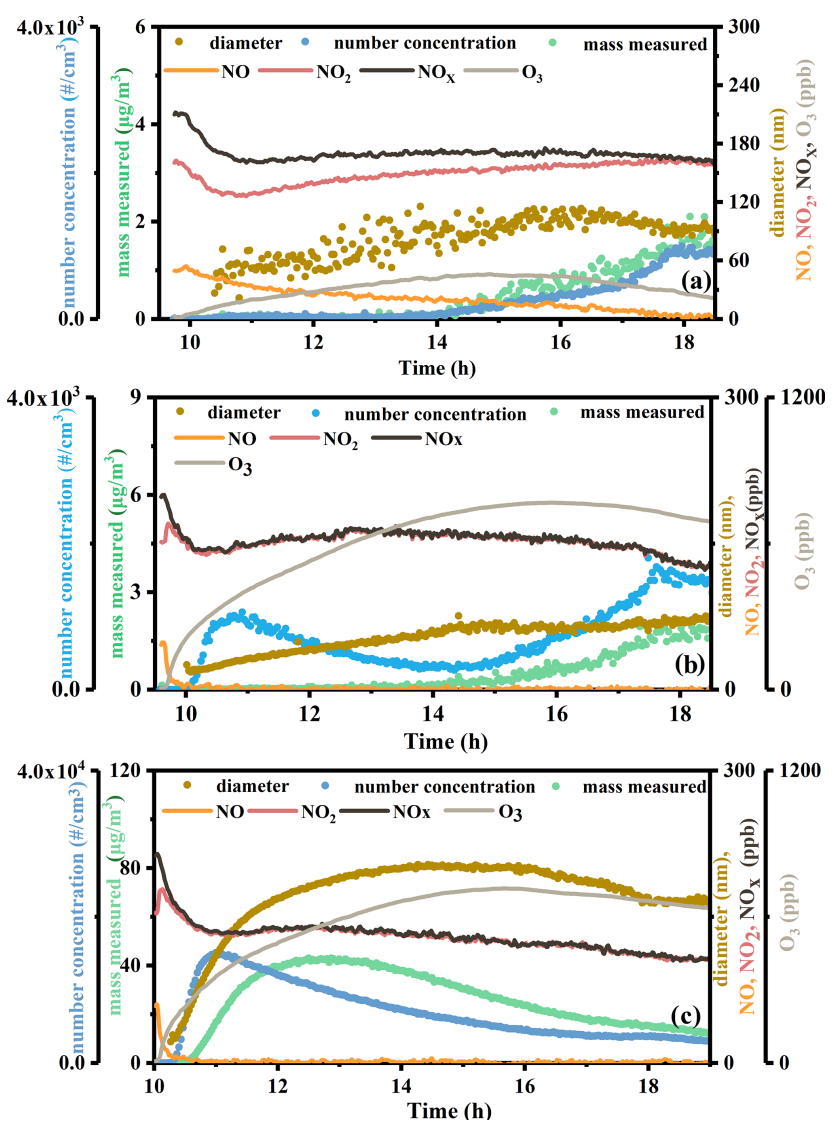

Figure 1. Reaction profiles of photooxidation of $n$-dodecane (a), 1,3,5-TMB (b), and mixed AVOCs (c) under $\mathrm{NO}_{x}$ conditions in summer. The concentrations of mass and number concentration of particles are shown on the left axes, while the diameter of particles and concentrations of $\mathrm{NO}, \mathrm{NO}_{2}, \mathrm{NO}_{x}$, and $\mathrm{O}_{3}$ are shown on the right axes.

where $\Delta M_{\mathrm{o}}\left(\mu \mathrm{g} \mathrm{m}^{-3}\right)$ was the mass concentration of the organic aerosol, and $\Delta \mathrm{ROG}\left(\mu \mathrm{g} \mathrm{m}^{-3}\right)$ was the amount of the ROG reacted.

For the mixed anthropogenic volatile organic compounds (AVOCs), the formed SOA mass was predicted based on the SOA precursors and their SOA yield measured in this study. The possible nonlinear interactions between the anthropogenic VOC mixtures were not taken into account. Specifically, the calculation equation (Kari et al., 2019) could be expressed as follows:

$\mathrm{SOA}_{\text {predicted }}=\sum_{i}\left(\Delta \mathrm{ROG}_{i} \times Y_{i}\right)$,

where $\Delta \mathrm{ROG}_{i}$ was the amount of the $\mathrm{ROG}_{i}$ reacted, and $Y_{i}$ was the SOA yield of $\mathrm{ROG}_{i}$.

\section{Results and discussion}

A set of experiments are conducted in summer, of which the initial conditions and general results are shown in

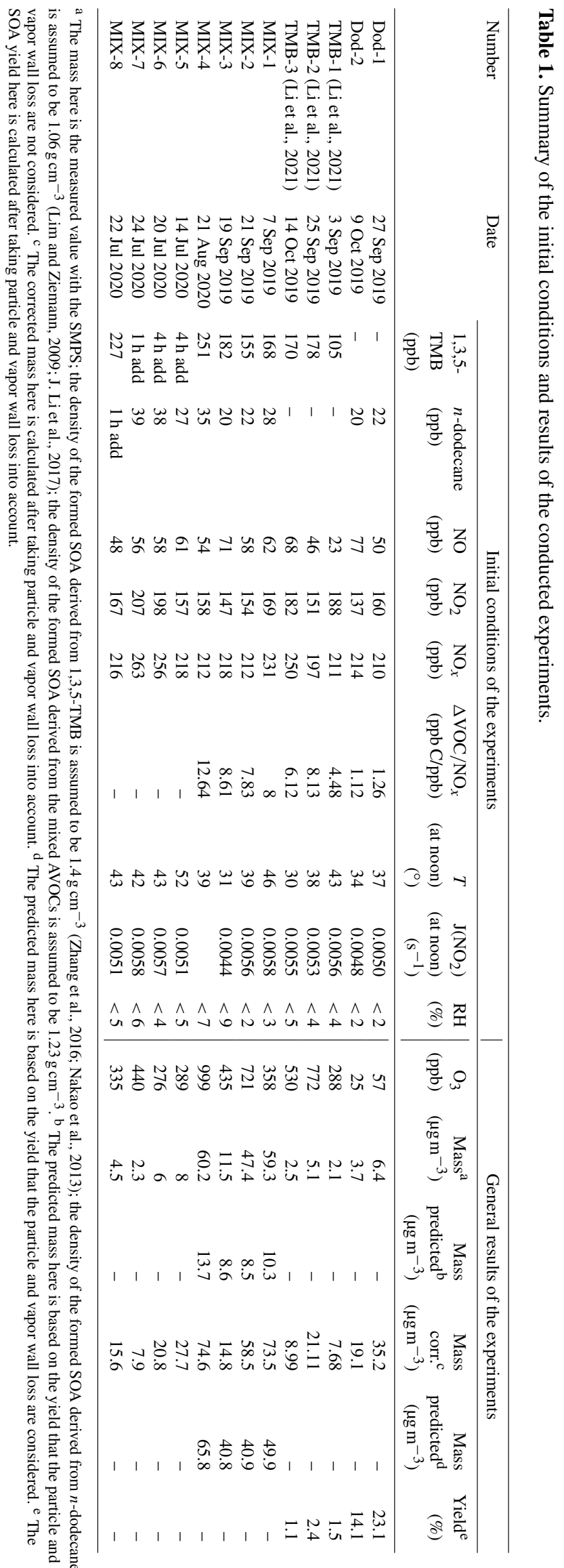

https://doi.org/10.5194/acp-21-7773-2021 


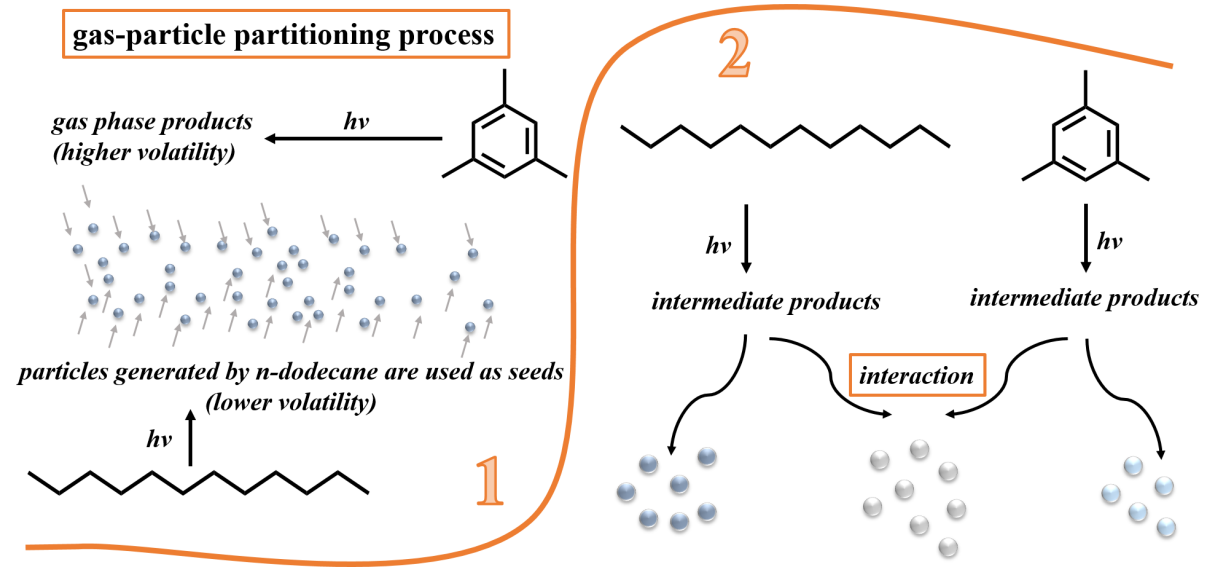

Figure 2. The possible conjectures of the reaction processes.

Table 1. The experiments are conducted as follows: $n$-dodecane $+\mathrm{HONO} ; 1,3,5$-trimethylbenzene $+\mathrm{HONO} ; n$ dodecane $+1,3,5$-trimethylbenzene + HONO. The experiments are conducted under similar conditions, and the details of the relative humidity $(\mathrm{RH})$, temperature $(T)$, and the $\mathrm{NO}_{2}$ photolysis rate $\left(\mathrm{J}\left(\mathrm{NO}_{2}\right)\right)$ of the experiments are shown in Fig. S1. Ng et al. (2007a) reported that the efficient photolysis of $\mathrm{HONO}$ (the same method with this study) could generate relatively high concentrations of $\mathrm{OH}$, 1 ppm $\mathrm{NO}_{x} \sim 2 \times 10^{7}$ molecules $\mathrm{cm}^{-3} \mathrm{OH}$ initially. The $\mathrm{NO}_{x}$ concentration applied in this work is in the range of 190$260 \mathrm{ppb}$, resulting in the estimated $\mathrm{OH}$ concentration being (4-5.2) $\times 10^{6}$ molecules $\mathrm{cm}^{-3}$ in the pure and mixed experiments. The $\mathrm{NO}_{2}$ photolysis rates of the experiments at noon in summer are in the range of $0.005-0.006 \mathrm{~s}^{-1}$; for the experiment MIX-3, the weather is cloudy, and the $\mathrm{J}\left(\mathrm{NO}_{2}\right)$ at noon is relatively smaller, $0.004 \mathrm{~s}^{-1}$. The temperature in summer at noon is in the range of $30-46^{\circ}$, and the RH inside the chamber is $<10 \%$. The reaction profiles of photooxidation of $n$-dodecane, 1,3,5-TMB, and mixed AVOCs under HONO conditions in summer are shown in Fig. 1. According to a previous study (Chen et al., 2019), the formed inorganic nitrate is negligible for the high- $\mathrm{NO}_{x}$ oxidation of gasoline, in which the experimental conditions are similar to this study $\left(\mathrm{NO}_{x} 130 \mathrm{ppb}\right.$, formed aerosol mass concentration $34.6 \mu \mathrm{g} \mathrm{m}^{-3}$ ). In the pure and mixed experiments, the $\mathrm{NO}_{x}$ concentration is equivalent, so the formed nitric acid should be similar. Therefore, the increase in particle mass concentration in the mixed experiments is likely from the organic aerosols.

The SOA yields of $n$-dodecane and 1,3,5-TMB are $14.1 \%-23.1 \%$ and $1.1 \%-2.4 \%$, respectively, as shown in Table 1 . The predicated SOA mass derived from the mixture of these VOCs is based on the measured SOA yields of $n$-dodecane and 1,3,5-TMB, without considering possible nonlinear interactions between them. Then the observed SOA mass is compared to the predicted values. It can be seen that nearly all the measured values are higher than the predicted SOA mass both before and after wall-loss correction. In other words, the SOA formation is enhanced when the two AVOCs are mixed, indicating the potential synergistic effect may exist in the mixed AVOC reaction system. The findings above will be discussed further in the following sections.

\subsection{Enhancement of SOA formation}

Figure 1 shows the formation and evolution of the SOA during the photochemical reaction processes in summer. The number mean diameter, number concentration, surface mean diameter, total surface, and mass concentration of the particles are analyzed and compared. The number mean diameters of the formed particles from $n$-dodecane, 1,3,5-TMB, and the mixture are 100, 50-100, and 150-200 nm, respectively. This suggests that after mixing the two precursors, the number mean diameter of the formed particle became larger. The number concentration of the formed particles, similarly, increased from $2.0 \times 10^{3} \mathrm{~cm}^{-3}$ for single precursors to above $1.0 \times 10^{4} \mathrm{~cm}^{-3}$ for the mixture. Because of the enhanced particle number concentration and diameter, the mass concentration of particles increases from $<4 \mu \mathrm{g} \mathrm{m}^{-3}$ for individual precursors to $>40 \mu \mathrm{g} \mathrm{m}^{-3}$ for the mixture. It can be seen that the mass concentration of SOA generated by the mixed AVOC system is significantly higher than the sum of the SOA generated by the two separate systems. It should be noted that the surface mean diameter of the particles from $n$-dodecane, 1,3,5-TMB, and the mixed AVOCs is all around $200 \mathrm{~nm}$. However, due to the enhanced number concentration for mixture, the total surface of the formed particles for the mixture $\left(>1.0 \times 10^{9} \mathrm{~nm}^{2} \mathrm{~cm}^{-3}\right)$ was higher than individual precursors $\left(<1.0 \times 10^{8} \mathrm{~nm}^{2} \mathrm{~cm}^{-3}\right.$ for $n$-dodecane; $<5.0 \times 10^{7} \mathrm{~nm}^{2} \mathrm{~cm}^{-3}$ for 1,3,5-TMB). Overall, after the two precursors are mixed, the number mean diameter, number concentration, total surface, and mass concentration of the generated particles were improved, while the surface mean diameter of the particles did not change. 

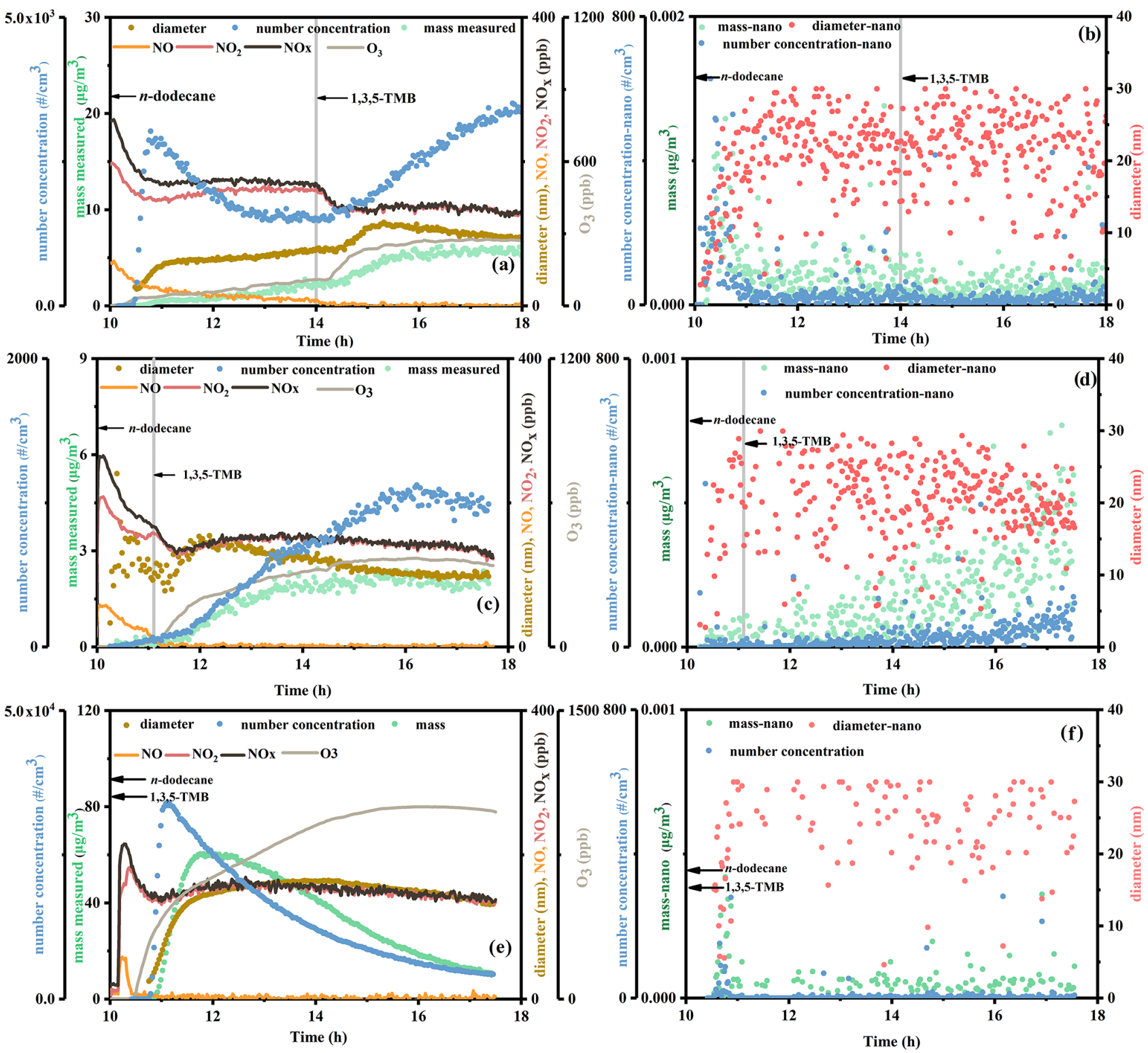

Figure 3. (a) Reaction profiles of experiment MIX-6, (b) time series of particles in the size range of 0-40 nm for MIX-6, (c) reaction profiles of experiment MIX-7, (d) time series of particles in the size range of $0-40 \mathrm{~nm}$ for MIX-7, (e) reaction profiles of experiment MIX-4, and (f) time series of particles in the size range of $0-40 \mathrm{~nm}$ for MIX-4. The concentrations of mass and number concentration of particles are shown on the left axes, while the diameter of particles and concentrations of $\mathrm{NO}, \mathrm{NO}_{2}, \mathrm{NO}_{x}$, and $\mathrm{O}_{3}$ are shown on the right axes. The vertical gray lines in the figures refer to the time that $1,3,5-\mathrm{TMB}$ was added.

From the results shown above, we know that the SOA yield is significantly enhanced when mixing $n$-dodecane and 1,3,5-TMB. Experimental conditions can influence the SOA yields; however, the effect is not obvious. First, precursor concentration may play a role; however, we can rule it out based on the analysis below. Several previous studies (Lauraguais et al., 2012; Loza et al., 2014; Zhou et al., 2011; $\mathrm{Ng}$ et al., 2007a) have reported that the aerosol formation is strongly affected by the initial precursor concentration, with a higher initial concentration of precursor leading to higher
SOA yields. As higher initial precursor concentration will produce a higher amount of condensable products through chemical processes, the formed SOA mass will be higher. The aerosol present in the system will directly affect the gasparticle partitioning; as the medium, it can adsorb the oxidation products. Thus, higher SOA mass will lead to higher SOA yield (Lauraguais et al., 2014). In this work, for TMB1 and TMB-2, while keeping the HONO concentration basically unchanged, the concentration of 1,3,5-TMB increases from $105 \mathrm{ppb}\left(514.5 \mu \mathrm{g} \mathrm{m}^{-3}\right)$ to $178 \mathrm{ppb}\left(882.9 \mu \mathrm{g} \mathrm{m}^{-3}\right)$; the 


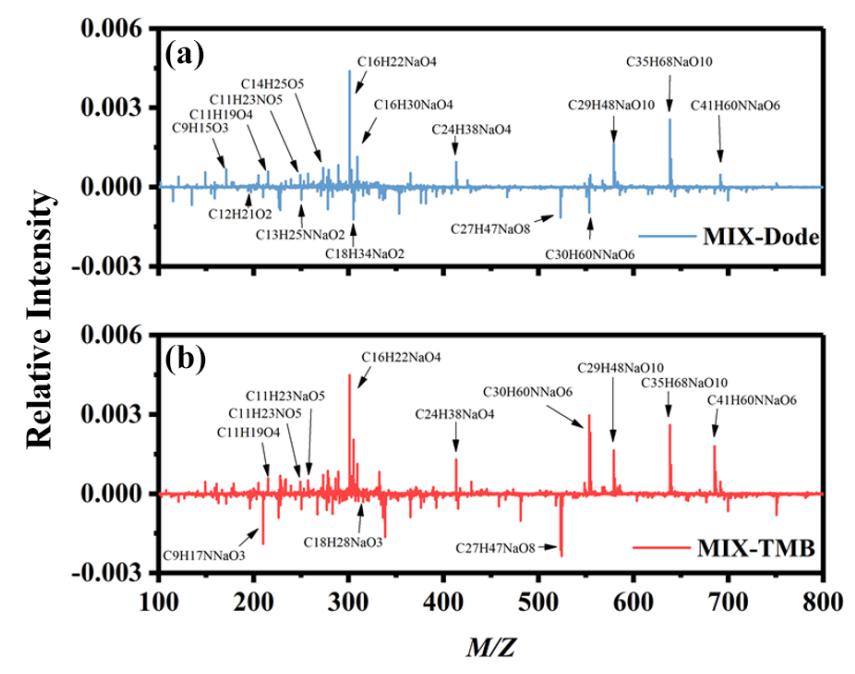

Figure 4. Results of mass spectra difference in (a) mixed AVOC SOA minus $n$-dodecane SOA and (b) mixed AVOC SOA minus $1,3,5$-TMB SOA. The $y$ axis is the relative intensity normalized by dividing by the total signal strength of the mass spectra.

yield increases by only $0.9 \%$. For the mixed AVOC reaction system, the concentrations of the precursors for MIX-1 and MIX-2 are 168 and $155 \mathrm{ppb}\left(824.2\right.$ and $756.2 \mu \mathrm{g} \mathrm{m}^{-3}$, $1,3,5-\mathrm{TMB})$ and 28 and $22 \mathrm{ppb}\left(194.7\right.$ and $152.3 \mu \mathrm{g} \mathrm{m}^{-3}$, $n$-dodecane), respectively. Compared with TMB-2 experiments, the concentration of MIX precursor is only increased by about 136 and $25.6 \mu \mathrm{g} \mathrm{m}^{-3}$ (3\%-15\%). According to the SOA yields of the TMB reaction system, the increase in the precursors mass concentration of the mixture system is not the reason for the large increase in the SOA mass concentration. Second, $\mathrm{NO}_{x}$ may also influence the SOA yield, but that is likely not the case here. Tsiligiannis et al. (2019) observed that the particle formation strongly varied with $\mathrm{NO}_{x}$ conditions, and the increasing $\mathrm{NO}_{x} / \Delta \mathrm{TMB}$ ratio would suppress the SOA formation. In this work, regardless of whether it is a single or a mixed reaction system, the $\mathrm{NO}_{x}$ concentration in the system remains basically unchanged. Experiments TMB2, MIX-1, and MIX-2 have a similar $\Delta \mathrm{VOC} / \mathrm{NO}_{x}$ ratio, all around $\sim 8$, but the formed SOA mass concentration is quite different. This indicates that the $\Delta \mathrm{VOC} / \mathrm{NO}_{x}$ ratio here has little effect on the enhanced SOA mass concentration of the mixed AVOC reaction system.

Rate constants for the reactions of $n$-dodecane and 1,3,5TMB with the $\mathrm{OH}$ radical at $298 \mathrm{~K}$ are $13.2 \times 10^{-12}$ and $56.7 \times 10^{-12} \mathrm{~cm}^{3}$ molecule $\mathrm{s}^{-1} \mathrm{~s}^{-1}$, respectively (Atkinson and Arey, 2003). As shown in Table S3, OH reactivity of Dod-1 and Dod-2 is about 6.5-7.1 s ${ }^{-1}$; OH reactivity of TMB-2 and TMB-3 is in the range of $237.1-248.3 \mathrm{~s}^{-1}$; and OH reactivity of MIX-1, MIX-2, MIX-3, and MIX-4 is in the range of $223.3-361.5 \mathrm{~s}^{-1}$. This indicates that $\mathrm{OH}$ reactivity of the mixed experiments differs greatly from that of dodecane experiments, but it is very close to that of $1,3,5-\mathrm{TMB}$ experiments. However, the mixed experiments still have a large enhancement in SOA formation compared with 1,3,5TMB experiments, indicating that this enhancement is likely not due to the different $\mathrm{OH}$ reactivity. Rate constants for the reactions of $\mathrm{NO}_{2}$ and $\mathrm{NO}$ with the $\mathrm{OH}$ radical at $298 \mathrm{~K}$ are $4.1 \times 10^{-11}$ and $3.3 \times 10^{-11} \mathrm{~cm}^{3}$ molecule ${ }^{-1} \mathrm{~s}^{-1}$, respectively (Atkinson et al., 2004). The $\mathrm{OH}$ reactivity of $\mathrm{NO}_{x}$ is similar for all experiments (189.6-238.8 $\mathrm{s}^{-1}$ ) and therefore likely plays a minor role in influencing SOA concentration.

For the enhancement in SOA yield of the mixed AVOC system, we propose two possible conjectures, as revealed in Fig. 2. The first conjecture is that the gas-particle partitioning of the system has changed. The SOA yield of $n$ dodecane $(14.1 \%-23.1 \%)$ is significantly higher than that of 1,3,5-TMB (1.1\%-2.4\%), so the volatility of its products (including gas phase and particle phase) is relatively lower, and it is easier to form particles, e.g., nucleation; for the 1,3,5-TMB reaction system, the products have higher volatility and are difficult to condense and nucleate, so the yield is lower. When 1,3,5-TMB is mixed with $n$-dodecane, the products of $n$-dodecane provide a lot of particles for the products of 1,3,5-TMB to condense, so the yield is greatly improved. Another conjecture is that there are chemical interactions between the two systems; i.e., the intermediate products of the two precursors may react with each other.

In order to know which conjecture is correct, different injection experiments are performed: $n$-dodecane and $\mathrm{HONO}$ are introduced into the chamber firstly, and after $1 \mathrm{~h}$ (Fig. 3c and d, MIX-6) or 4h (Fig. 3a and b, MIX-7) of photochemical reaction, 1,3,5-TMB is introduced into the chamber. As shown in Fig. 3a and c, after the introduction of 1,3,5-TMB, the mass and number concentration of the particles have a certain increase, and the consumption of $\mathrm{NO}_{x}$ is accelerated. However, compared with Fig. 3e (n-dodecane and 1,3,5TMB are added together before the photochemical experiments, MIX-4), the final SOA mass concentrations of MIX-6 and MIX-7 (Fig. 3a and c) are much lower. If our first conjecture plays an important role, one would expect large SOA mass enhancement (similar with mixed experiments) as the products of $n$-dodecane provide enough condensational sink for 1,3,5-TMB products to condense. The result here indicates that the gas-particle partitioning conjecture plays a minor role in the SOA yield enhancement. To further verify our second conjecture, the particle compositions are analyzed and shown below.

Figure 4 shows the ESI-ToF-MS mass spectra of SOA generated from $n$-dodecane, 1,3,5-TMB, and mixed AVOCs. The representative identified products with strong intensity are shown in Fig. S2 and Table 2. The identified products are mainly based on the mass spectra and previous related studies (Tsiligiannis et al., 2019; J. Li et al., 2017; Sato et al., 2019). As shown in Fig. 4, most products from $n$-dodecane, $1,3,5-\mathrm{TMB}$, and mixed AVOC SOA are concentrated around $\mathrm{m} / \mathrm{z} 200-450$; in the range of $\mathrm{m} / \mathrm{z} 500-700$, oligomers are formed. 
Table 2. Representative identified mass spectral peaks, molecular formulas, molecular weights, and relative intensity of $n$-dodecane, $1,3,5$ TMB, and mixed AVOC-derived SOA.

\begin{tabular}{|c|c|c|c|c|c|}
\hline Molecular formula & $\mathrm{M}+\mathrm{H}$ & $\mathrm{M}+\mathrm{Na}$ & $\begin{array}{r}\text { MIX relative } \\
\text { intensity }\left(\times 10^{-3}\right)\end{array}$ & $\begin{array}{r}\text { TMB relative } \\
\text { intensity }\left(\times 10^{-3}\right)\end{array}$ & $\begin{array}{r}n \text {-Dodecane } \\
\text { relative } \\
\text { intensity }\left(\times 10^{-3}\right)\end{array}$ \\
\hline $\mathrm{C}_{9} \mathrm{H}_{14} \mathrm{O}_{3}$ & 171.099 & & 1.41 & 1.73 & 0.733 \\
\hline $\mathrm{C}_{9} \mathrm{H}_{17} \mathrm{NO}_{3}$ & & 210.111 & 0.484 & 2.38 & 0.864 \\
\hline $\mathrm{C}_{11} \mathrm{H}_{18} \mathrm{O}_{4}$ & 215.126 & & 0.641 & 0.0563 & 0.0489 \\
\hline $\mathrm{C}_{14} \mathrm{H}_{22} \mathrm{O}_{3}$ & 239.166 & & 0.217 & 0.0526 & 0.0489 \\
\hline $\mathrm{C}_{14} \mathrm{H}_{20} \mathrm{O}_{2}$ & & 243.134 & 0.113 & 0.0966 & 0.110 \\
\hline $\mathrm{C}_{11} \mathrm{H}_{22} \mathrm{NO}_{5}$ & 249.158 & & 0.489 & 0.0583 & 0.0718 \\
\hline $\mathrm{C}_{14} \mathrm{H}_{26} \mathrm{O}_{2}$ & & 249.183 & 0.503 & 0.0495 & 0.0459 \\
\hline $\mathrm{C}_{13} \mathrm{H}_{25} \mathrm{NO}_{2}$ & & 250.177 & 1.22 & 1.79 & 1.69 \\
\hline $\mathrm{C}_{8} \mathrm{H}_{12} \mathrm{O}_{9}$ & 253.056 & & 0.220 & 0.0308 & 0.0109 \\
\hline $\mathrm{C}_{11} \mathrm{H}_{22} \mathrm{O}_{5}$ & & 257.135 & 0.535 & 0.0265 & 0.0223 \\
\hline $\mathrm{C}_{12} \mathrm{H}_{20} \mathrm{O}_{6}$ & 261.131 & & 0.387 & 0.284 & 0.393 \\
\hline $\mathrm{C}_{15} \mathrm{H}_{28} \mathrm{O}_{2}$ & & 263.199 & 0.250 & 0.0808 & 0.0427 \\
\hline $\mathrm{C}_{14} \mathrm{H}_{24} \mathrm{O}_{5}$ & 273.167 & & 0.799 & 0.0872 & 0.0643 \\
\hline $\mathrm{C}_{16} \mathrm{H}_{22} \mathrm{O}_{4}$ & 279.159 & & 0.728 & 0.139 & 0.0724 \\
\hline $\mathrm{C}_{14} \mathrm{H}_{26} \mathrm{O}_{4}$ & & 281.172 & 0.305 & 0.0685 & 0.0427 \\
\hline $\mathrm{C}_{18} \mathrm{H}_{28} \mathrm{O}$ & & 283.207 & 1.14 & 1.83 & 1.46 \\
\hline $\mathrm{C}_{13} \mathrm{H}_{22} \mathrm{NO}_{6}$ & 289.153 & & 0.890 & 0.0513 & 0.0565 \\
\hline $\mathrm{C}_{16} \mathrm{H}_{22} \mathrm{O}_{4}$ & & 301.146 & 4.77 & 1.09 & 1.41 \\
\hline $\mathrm{C}_{18} \mathrm{H}_{34} \mathrm{O}_{2}$ & & 305.263 & 3.26 & 1.22 & 0.004 .4 \\
\hline $\mathrm{C}_{16} \mathrm{H}_{30} \mathrm{O}_{4}$ & & 309.202 & 1.28 & 0.149 & 0.135 \\
\hline $\mathrm{C}_{18} \mathrm{H}_{28} \mathrm{O}_{3}$ & & 315.194 & 0.936 & 1.25 & 1.26 \\
\hline $\mathrm{C}_{16} \mathrm{H}_{24} \mathrm{O}_{5}$ & & 319.151 & 2.09 & 0.0290 & 0.0197 \\
\hline $\mathrm{C}_{20} \mathrm{H}_{34} \mathrm{O}_{2}$ & & 329.246 & 0.319 & 0.0927 & 0.133 \\
\hline $\mathrm{C}_{19} \mathrm{H}_{38} \mathrm{O}_{4}$ & & 353.267 & 1.42 & 1.46 & 2.42 \\
\hline $\mathrm{C}_{24} \mathrm{H}_{38} \mathrm{O}_{4}$ & & 413.266 & 2.69 & 1.39 & 1.74 \\
\hline $\mathrm{C}_{20} \mathrm{H}_{34} \mathrm{O}_{8}$ & & 425.214 & 0.297 & 0.395 & 0.0333 \\
\hline $\mathrm{C}_{24} \mathrm{H}_{36} \mathrm{NaO}_{5}$ & & 427.245 & 0.107 & 0.108 & 0.0393 \\
\hline $\mathrm{C}_{27} \mathrm{H}_{48} \mathrm{O}_{8}$ & & 523.325 & 0.183 & 1.54 & 1.33 \\
\hline $\mathrm{C}_{30} \mathrm{H}_{60} \mathrm{NO}_{6}$ & & 553.459 & 3.08 & 0.145 & 3.32 \\
\hline $\mathrm{C}_{28} \mathrm{H}_{48} \mathrm{O}_{10}$ & & 567.307 & 0.272 & 0.0195 & 0.0215 \\
\hline $\mathrm{C}_{29} \mathrm{H}_{48} \mathrm{O}_{10}$ & & 579.296 & 1.54 & 0.0150 & 0.0167 \\
\hline $\mathrm{C}_{35} \mathrm{H}_{68} \mathrm{O}_{10}$ & & 639.480 & 1.2 & 0.109 & 0.134 \\
\hline $\mathrm{C}_{41} \mathrm{H}_{60} \mathrm{NO}_{6}$ & & 685.434 & 2.01 & 0.209 & 2.11 \\
\hline
\end{tabular}

Huang et al. (2015) reported that the predominant products for the aging of 1,3,5-trimethylbenzene secondary organic aerosol were organic nitrogen-containing products, aromatic organic acid, oxocarboxylic acid, and oligomer compounds. Due to the various $\mathrm{NO}_{x} / \Delta \mathrm{TMB}$ ratios, the formed products might be different. Usually, higher NO would lead to the suppression of oligomers and particle formation, and higher NO would increase the formation of organonitrates (Tsiligiannis et al., 2019). The products derived from $n$-dodecane in the presence of $\mathrm{NO}_{x}$ were mainly oxygen-containing organic compounds (i.e., peroxyhemiacetals, hemiacetals, esters, aldol condensation) and organonitrate products (Fahnestock et al., 2015; Lim and Ziemann, 2005). As shown in Table 2, the products derived from 1,3,5-TMB are mainly organonitrates and oxygen-containing organic compounds. For products derived from $n$-dodecane, the main components are also oxygen-containing organic compounds and organic nitrates. It should be noted that in the mixed AVOC system, some products are not detected in the separate reaction system (n-dodecane or 1,3,5-TMB), such as $\mathrm{C}_{16} \mathrm{H}_{30} \mathrm{O}_{4}, \mathrm{C}_{16} \mathrm{H}_{24} \mathrm{O}_{5}$, $\mathrm{C}_{29} \mathrm{H}_{48} \mathrm{O}_{10}$, and $\mathrm{C}_{35} \mathrm{H}_{68} \mathrm{O}_{10}$. This indicates that interactions occur between the intermediate products from $n$-dodecane and 1,3,5-TMB.

The gas-phase products of $\mathrm{OH}$-initiated oxidation of 1,3,5TMB in the presence of $\mathrm{NO}_{x}$ are mainly 3,5-dimethyl benzaldehyde $\left(\mathrm{C}_{9} \mathrm{H}_{10} \mathrm{O}\right), 3$,5-dimethylbenzoic acid $\left(\mathrm{C}_{9} \mathrm{H}_{10} \mathrm{O}_{2}\right)$, 2-methyl-4-oxo-2-pentenal $\left(\mathrm{C}_{6} \mathrm{H}_{8} \mathrm{O}_{2}\right)$, 2-methyl-4-oxo-2pentenoic acid $\left(\mathrm{C}_{6} \mathrm{H}_{8} \mathrm{O}_{3}\right), 2,4,6$-trimethylphenol $\left(\mathrm{C}_{9} \mathrm{H}_{12} \mathrm{O}\right)$, and 3,5-dimethyl-2-furanone $\left(\mathrm{C}_{6} \mathrm{H}_{8} \mathrm{O}_{2}\right)$ (Huang et al., 2015), which contain carbonyl or hydroxyl groups that are formed within $1 \mathrm{~h}$ photochemical reaction. The intermediate products of $\mathrm{OH}$-initiated oxidation of $n$-dodecane in the pres- 

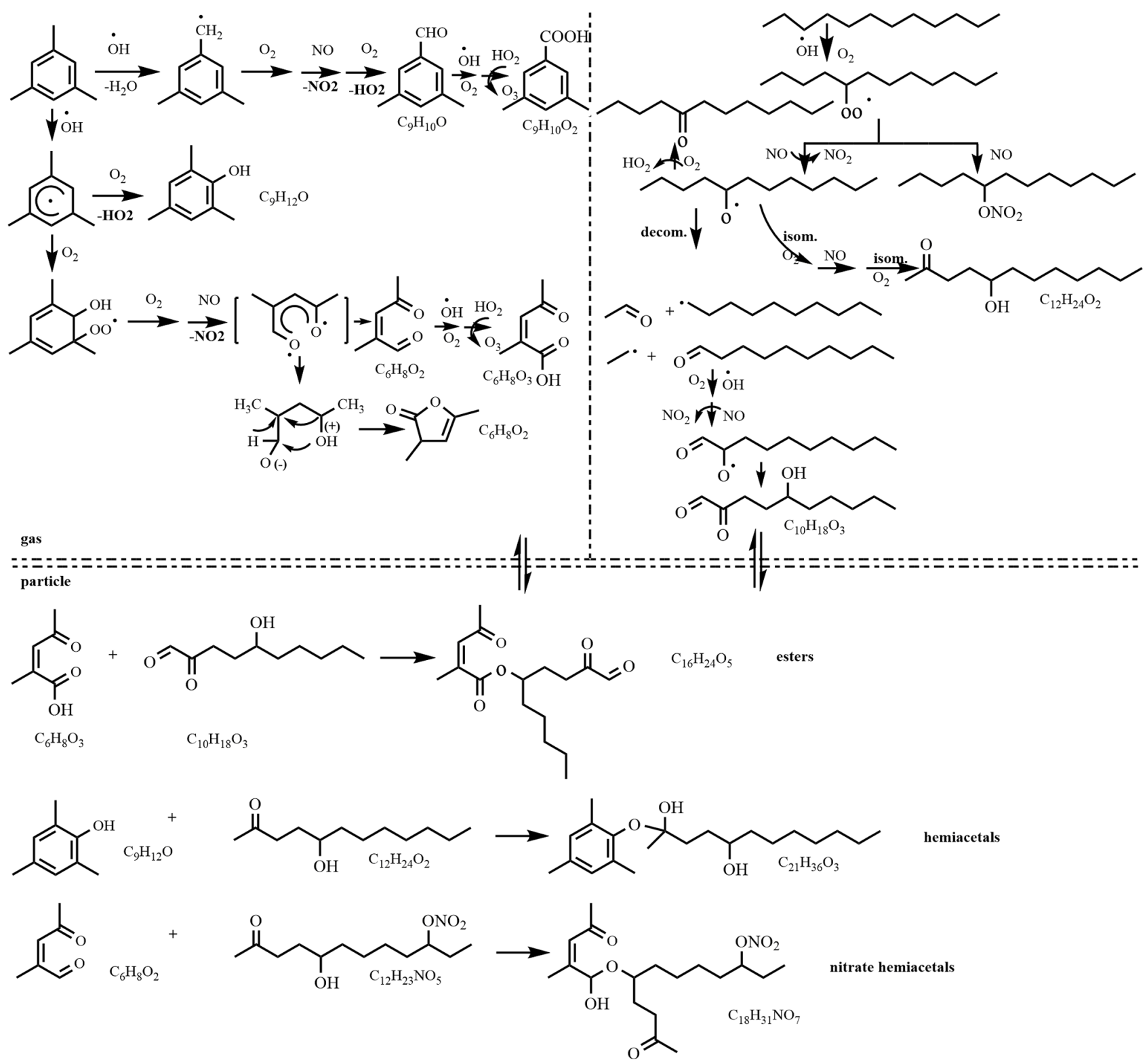

nitrate hemiacetals

Figure 5. Proposed reaction mechanism of the mixed AVOC system in the presence of $\mathrm{NO}_{x}(\mathrm{R} 1$ and $\mathrm{R} 2$ are alkyl groups or aromatic hydrocarbon groups).

ence of $\mathrm{NO}_{x}$ are also compounds containing carbonyl and hydroxyl groups, and more alcohol can be formed due to the $\mathrm{RO}_{2}+\mathrm{NO}$ reaction compared to the low- $\mathrm{NO}_{x}$ condition (Fahnestock et al., 2015). These compounds tend to undergo an acetal reaction and/or esterification reaction in the particle phase. When the photochemical reaction is initiated, the intermediate products produced by 1,3,5-TMB and $n$-dodecane exist in the same reaction system, and acetal and esterification reactions are more likely to occur in the particle phase due to higher concentration of aldehydes, ketones, alcohols, and carboxylic acids. The proposed reaction mechanism of the mixed AVOC system is shown in Fig. 5. As an example, $\mathrm{C}_{16} \mathrm{H}_{24} \mathrm{O}_{5}$, which has a much higher intensity in the mixed
AVOC system (as shown in Table 2 and discussed above), might be an ester from the reaction of an acid and an alcohol from 1,3,5-TMB and $n$-dodecane, respectively.

\subsection{Light absorption of secondary organic aerosol}

Figure 6a shows the UV-Vis spectra of the $n$-dodecane, 1,3,5-TMB, and mixed AVOC SOA filter extract. Before analyzing the samples, the blank PTFE membrane filter is dissolved with methanol, and the ultraviolet-visible absorption spectrum of the methanol solution is analyzed. The absorption of the SOA filter solutions is mainly concentrated in the wavelength of $<300 \mathrm{~nm}$. This is consistent with previ- 

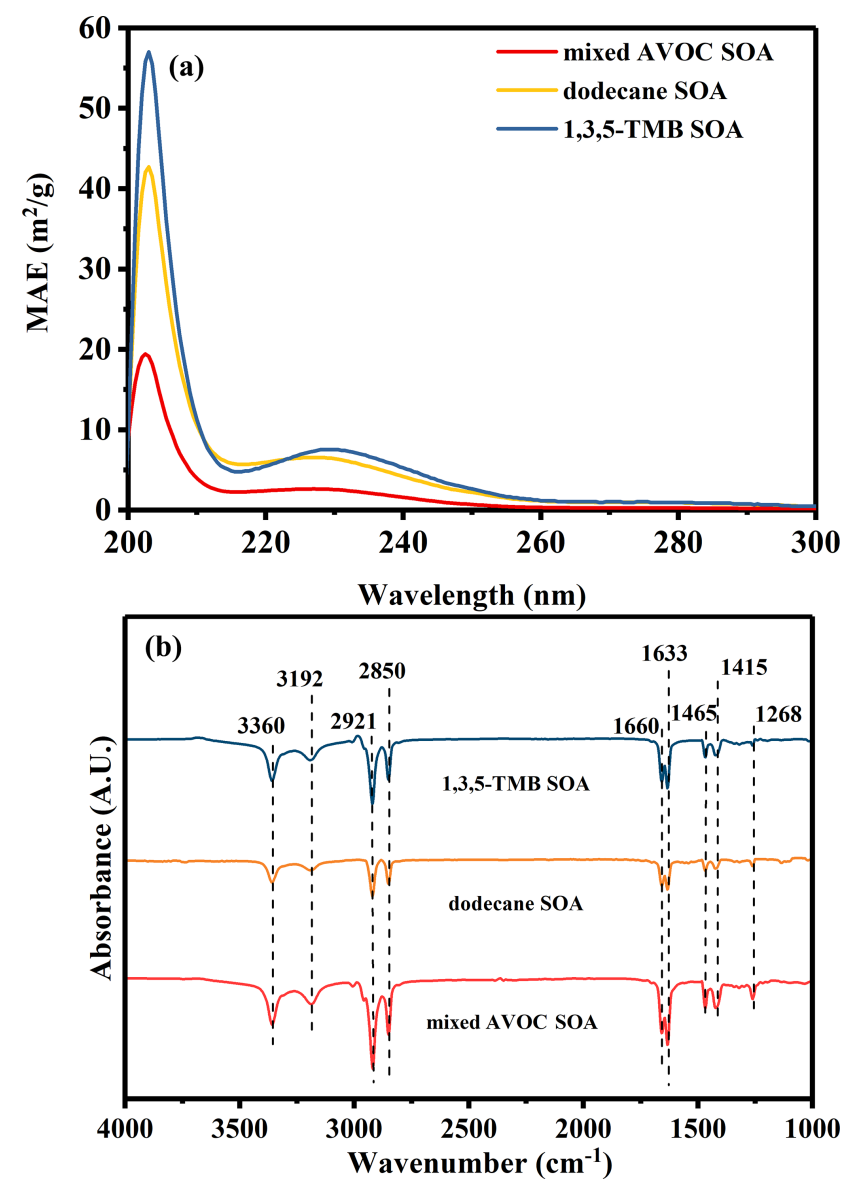

Figure 6. (a) UV-Vis spectra (MAE) of the $n$-dodecane, 1,3,5TMB, and mixed AVOC SOA. As the absorbance at wavelengths $>300 \mathrm{~nm}$ is negligible, we only show the range from 200 to $300 \mathrm{~nm}$. (b) ATR-IR spectra for the $n$-dodecane, 1,3,5-TMB, and mixed AVOC SOA using a background spectrum obtained without a sample as the reference.

ous literature reports: J. Li et al. (2017) found that the $n$ dodecane SOA solutions had no detectable absorption in the wavelength of $>350 \mathrm{~nm}$; Huang et al. (2018) found that the 1,3,5-TMB SOA solutions also had no obvious absorption in the wavelength of $>300 \mathrm{~nm}$. Based on the light absorption spectra, the mass absorption efficiency (MAE; $\mathrm{m}^{2} \mathrm{~g}^{-1}$ ) of the SOA in the extracts is calculated using the following equation (Chen et al., 2016):

$\operatorname{MAE}(\lambda)=\ln (10) \operatorname{Abs}(\lambda) / C_{\mathrm{OM}}$,

where $\operatorname{Abs}(\lambda)$ is the light absorption coefficient $\left(\mathrm{m}^{-1}\right)$, and $C_{\mathrm{OM}}$ is the SOA mass concentrations in the extracts. The MAE of the SOA extracts in Fig. 6a was calculated from 200 to $300 \mathrm{~nm}$. The MAE values at $205 \mathrm{~nm}$ were in the following order: 1,3,5-TMB SOA $\left(56.8 \mathrm{~m}^{2} \mathrm{~g}^{-1}\right)>$ dodecane SOA $\left(42.5 \mathrm{~m}^{2} \mathrm{~g}^{-1}\right)>$ mixed AVOC SOA $\left(19.5 \mathrm{~m}^{2} \mathrm{~g}^{-1}\right)$. The MAE in the $210-250 \mathrm{~nm}$ band also shows the same pattern. This indicates that the SOA generated by the mixed AVOCs con- tains less light-absorbing substance per unit mass relative to dodecane SOA and 1,3,5-TMB SOA.

To further determine the potential functional groups in SOA extracts, ATR-IR spectra were acquired (Fig. 6b). To eliminate the influence of water, experiments were conducted under dry conditions. As shown in Fig. $6 \mathrm{~b}$ and Table S4, the bold peak at $3360 \mathrm{~cm}^{-1}$ corresponds to the characteristic peak of $\mathrm{C}-\mathrm{OH}$ in alcohol. The peak at $3192 \mathrm{~cm}^{-1}$ originates from the $\mathrm{O}-\mathrm{H}$ stretching vibration of carboxylic acid. The two characteristic peaks at 2921 and $2850 \mathrm{~cm}^{-1}$ correspond to the $\mathrm{C}-\mathrm{H}$ stretching vibration of alkane. The peaks at 1660 and $1633 \mathrm{~cm}^{-1}$ originate from $\mathrm{C}=\mathrm{O}$ stretching vibrations. The signals at 1465 and $1415 \mathrm{~cm}^{-1}$ represent the deformation vibrations of methyl and methylene groups. The peak around $1268 \mathrm{~cm}^{-1}$ corresponds to the vibration of nitrate groups in nitrate ester. The results above suggest that the SOA extracts are dominantly composed of carbonyl compounds, carboxylic acid, nitrate ester, and alcohol. This is consistent with previous studies (Huang et al., 2015; Fahnestock et al., 2015).

\subsection{Factors affecting the formation of SOA and ozone}

According to previous studies, ozone concentration was statistically positively correlated with temperature, solar radiation intensity, and sunshine hours and was negatively correlated with precipitation, relative humidity $(\mathrm{RH})$, visibility, and wind speed (Wang et al., 2017; Huang et al., 2019; Jaffe and Zhang, 2017). The factors affecting ozone generation included solar radiation intensity, temperature, and precursor concentrations. Figure 7 shows the generation of ozone during the photochemical reactions of three different reaction systems. As shown in Fig. 7a, for the $n$-dodecane reaction system, the ozone concentration was Dod-1 $>$ Dod-2. As revealed by Table $\mathrm{S} 2$ and Fig. S1, under a similar $\Delta \mathrm{VOC} / \mathrm{NO}_{x}$ ratio and solar radiation intensity $\left(\mathrm{J}\left(\mathrm{NO}_{2}\right)\right)$, the higher temperature would promote the formation of ozone. For the 1,3,5-TMB reaction system, the formed ozone concentration was in the following order: TMB-2 $>$ TMB-3 $>$ TMB1. The corresponding $\Delta \mathrm{VOC} / \mathrm{NO}_{x}$ ratio was $8.13,6.12$, and 4.48 , respectively. The temperature conditions were TMB-1 > TMB-2 > TMB-3. The $\mathrm{J}\left(\mathrm{NO}_{2}\right)$ was similar for the three experiments. With similar solar radiation intensity, the $\Delta \mathrm{VOC} / \mathrm{NO}_{x}$ ratio of precursors played a decisive role in the generation of ozone concentration compared to the temperature conditions. For the mixed AVOC reaction system, the order of formed ozone concentration was MIX-2 > MIX-1. The corresponding $\Delta \mathrm{VOC} / \mathrm{NO}_{x}$ ratio was 7.83 and 8 ; the $\mathrm{J}\left(\mathrm{NO}_{2}\right)$ was MIX-1 $\sim$ MIX-2. The TMB/Dod ratio was 7 and 6 . This indicated that, under a similar $\Delta \mathrm{VOC} / \mathrm{NO}_{x}$ ratio and $\mathrm{J}\left(\mathrm{NO}_{2}\right)$ conditions, a higher TMB/Dod ratio would promote the formation of ozone. For experiments MIX-2 and MIX-3, the $\triangle \mathrm{VOC} / \mathrm{NO}_{x}$ ratios were similar, the temperature conditions were MIX-2 $>$ MIX-3, and the $\mathrm{J}\left(\mathrm{NO}_{2}\right)$ was MIX-2 $\sim$ MIX3 , and the TMB/Dod ratios were 9.1 and 7 . The conditions 

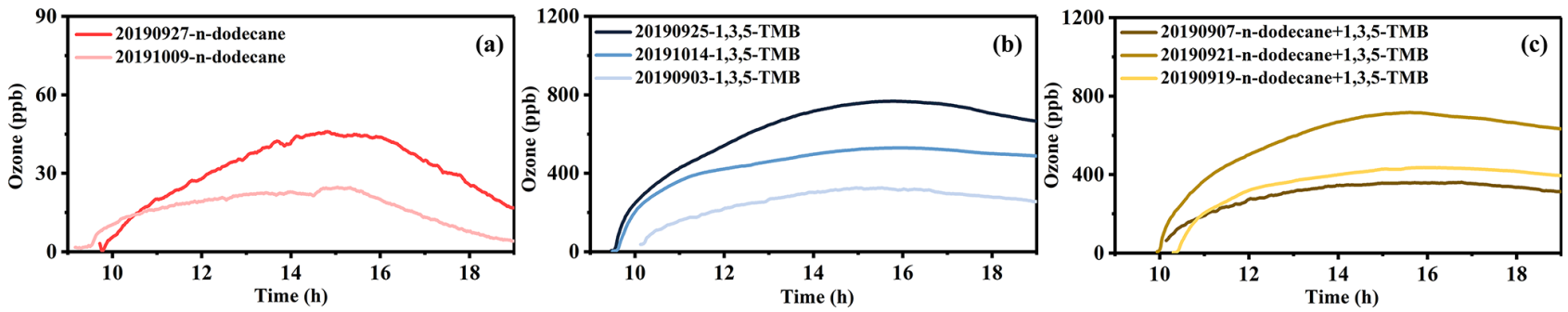

Figure 7. Ozone formation during the photochemical processes of $n$-dodecane (a), 1,3,5-TMB (b), and mixed AVOCs (c).

above indicated that the higher TMB/Dod ratio played a decisive role in the generation of ozone concentration. Higher temperature and a higher $\Delta \mathrm{VOC} / \mathrm{NO}_{x}(\mathrm{ppbC} / \mathrm{ppb})$ ratio in a separate reaction system will promote the generation of ozone; the relative content of reaction precursors $(\mathrm{ppb} / \mathrm{ppb})$ in the mixture system will affect the concentration of ozone. With a similar $\Delta \mathrm{VOC} / \mathrm{NO}_{x}$ ratio, a higher concentration of 1,3,5-TMB will promote ozone generation.

As shown in Fig. 8, for the $n$-dodecane reaction system, the mass concentration, number concentration, and total surface of the particles were Dod- $1<$ Dod-2. According to Fig. S1 and Table S2, under a similar $\Delta \mathrm{VOC} / \mathrm{NO}_{x}$ ratio and $\mathrm{J}\left(\mathrm{NO}_{2}\right)$, the lower temperature would promote the formation of particles. However, the surface mean and number mean diameter of the two experiments were around 100 and $200 \mathrm{~nm}$; this indicated that temperature had little effect on the diameter of the formed particles. For the 1.3.5-TMB reaction system, under similar $\mathrm{J}\left(\mathrm{NO}_{2}\right)$, lower temperature and a higher $\Delta \mathrm{VOC} / \mathrm{NO}_{x}$ ratio would promote the particle formation; temperature and the $\Delta \mathrm{VOC} / \mathrm{NO}_{x}$ ratio had little effect on the particle diameters. For the mixed experiments, under a similar $\Delta \mathrm{VOC} / \mathrm{NO}_{x}$ ratio, compared with $\mathrm{J}\left(\mathrm{NO}_{2}\right)$ and temperature, a higher Dod/TMB ratio would promote particle formation; similarly, the above conditions had little effect on the particle size. Lower temperature and a higher $\Delta \mathrm{VOC} / \mathrm{NO}_{x}(\mathrm{ppbC} / \mathrm{ppb})$ ratio in a separate reaction system will promote particle formation; the relative content of reaction precursors $(\mathrm{ppb} / \mathrm{ppb})$ in the mixture system will affect the formed particles. With a similar $\Delta \mathrm{VOC} / \mathrm{NO}_{x}$ ratio, a higher concentration of $n$-dodecane would promote the generation of particles; reaction conditions have little effect on the size of the final particle size.

\section{Atmospheric implications}

Our findings demonstrate that the SOA yield derived from the mixed anthropogenic volatile organic compounds ( $n$ dodecane + 1,3,5-TMB) in the presence of HONO is higher than the predicted value. The results of this work further demonstrate the inaccuracy of the SOA yield calculation method for the VOCs mixture, i.e., the simple linear addition of SOA yields from the individual yield of the compound in the VOC mixture. This calculation method may underesti- mate or overestimate the SOA production. In this work, the SOA production from the mixed $n$-dodecane and 1,3,5-TMB is underestimated. In the general case, the SOA yields from the individual compounds should be used with caution when calculating the SOA yields from the VOC mixture. In addition, as the representative substances of motor-vehicle exhaust, long-chain alkanes and aromatic hydrocarbons exist in the atmosphere at the same time. The increase in SOA yield after mixing the two kinds of compounds gives us an insight into the SOA yield derived from vehicular exhaust. Our results indicate that SOA formation needs to be considered more realistically in the atmosphere.

\section{Conclusions}

In summary, a set of photochemical experiments are carried out in a large-scale outdoor smog chamber. The measured SOA mass concentration of the mixed AVOCs ( $n$ dodecane $+1,3,5-\mathrm{TMB}$ ) is compared to the predicted SOA mass concentration based on the SOA mass yields of the individual compounds. Results show that the SOA formation from the mixed AVOCs is enhanced. Mass spectra of the SOA particles indicate that interaction occurs between the intermediate products from the two precursors, and the products previously present in the gas phase may enter the particle phase through this inter-reaction. This could be the main reason for the enhanced SOA production from the mixed AVOC reaction system. The SOA formation and the ozone formation vary with the $\mathrm{NO}_{x} / \mathrm{VOC}$ ratio, the temperature, and the solar radiation intensity.

Further research is needed to study the SOA chemistry from biogenic-biogenic VOC mixtures, biogenicanthropogenic VOC mixtures, and anthropogenicanthropogenic VOC mixtures. The interactions between VOC mixtures and the effect on SOA formation need to be determined. 

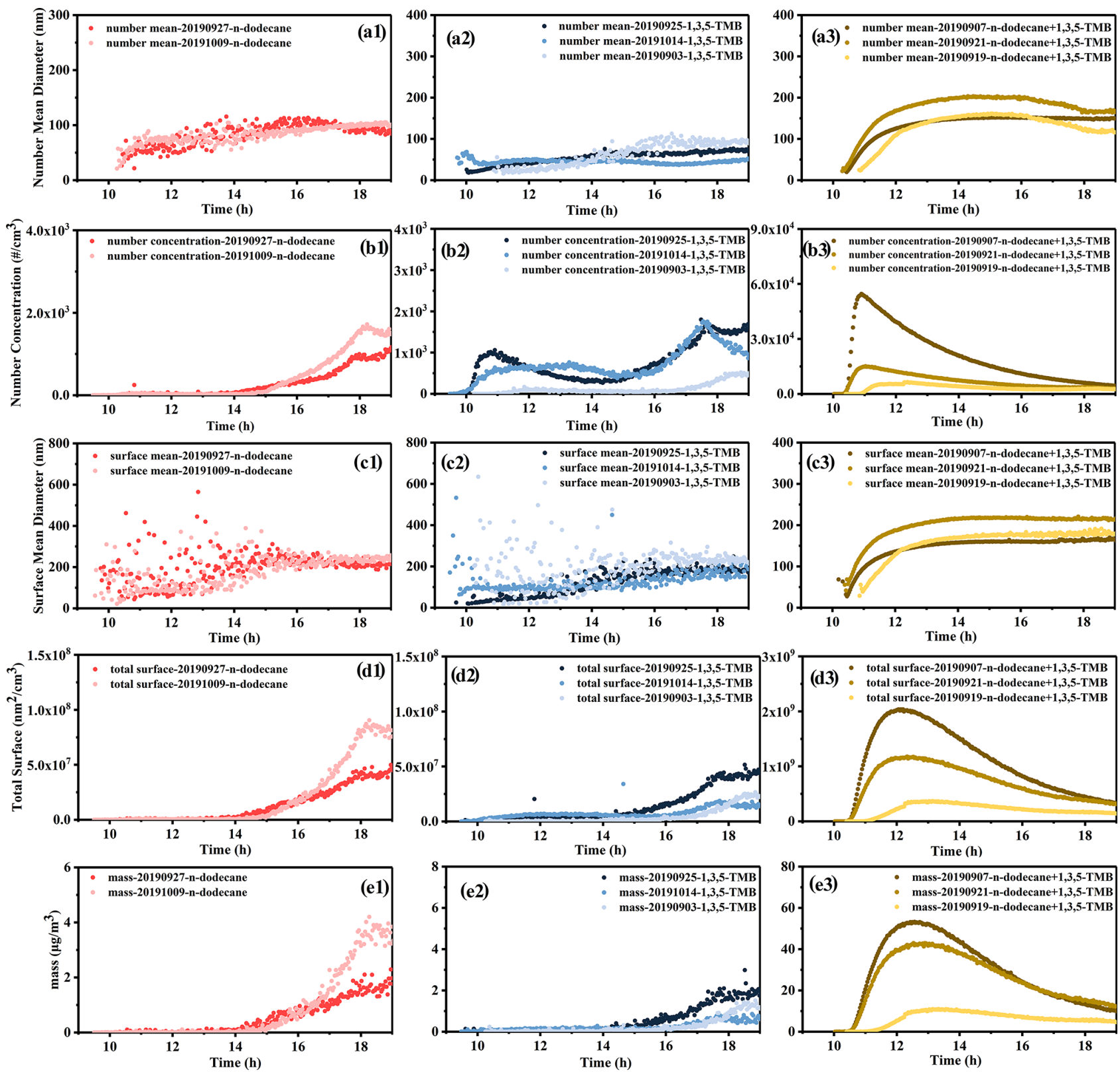

Figure 8. The formation and evolution of particles during the photochemical reactions in summer. The number mean diameter of particles derived from $n$-dodecane (a1), 1,3,5-TMB (a2), mixed AVOCs (a3); the number concentration of particles derived from $n$-dodecane (b1), 1,3,5-TMB (b2), mixed AVOCs (b3); the surface mean diameter of particles derived from $n$-dodecane (c1), 1,3,5-TMB (c2), mixed AVOCs (c3); the total surface of particles derived from $n$-dodecane (d1), 1,3,5-TMB (d2), mixed AVOCs (d3); the mass concentration of particles derived from $n$-dodecane (e1), 1,3,5-TMB (e2), mixed AVOCs (e3).

Data availability. The data used in this study are available upon request from the corresponding author.

Supplement. The supplement related to this article is available online at: https://doi.org/10.5194/acp-21-7773-2021-supplement.
Author contributions. JL and HL conceived and led the studies. JL, $\mathrm{KL}, \mathrm{YC}, \mathrm{HZ}, \mathrm{XZ}$, and ZW performed chamber simulation and data analysis. HL, YL, XW, WW, and MG discussed the results and commented on the paper. JL prepared the article with contributions from all co-authors.

Competing interests. The authors declare that they have no conflict of interest. 
Acknowledgements. We would like to thank Bin Liang from Bruker for supporting us with the mass spectrometry analysis.

Financial support. This research has been supported by the Beijing Municipal Science \& Technology Commission (grant no. Z181100005418015), the China Postdoctoral Science Foundation (grant no. 2019M660752), and LAC/CMA (grant no. 2019B08).

Review statement. This paper was edited by Roya Bahreini and reviewed by two anonymous referees.

\section{References}

Aimanant, S. and Ziemann, P. J.: Chemical mechanisms of aging of aerosol formed from the reaction of $n$-pentadecane with $\mathrm{OH}$ radicals in the presence of $\mathrm{NO}_{x}$, Aerosol Sci. Tech., 47, 979-990, https://doi.org/10.1080/02786826.2013.804621, 2013.

Appel, K. W., Napelenok, S. L., Foley, K. M., Pye, H. O. T., Hogrefe, C., Luecken, D. J., Bash, J. O., Roselle, S. J., Pleim, J. E., Foroutan, H., Hutzell, W. T., Pouliot, G. A., Sarwar, G., Fahey, K. M., Gantt, B., Gilliam, R. C., Heath, N. K., Kang, D., Mathur, R., Schwede, D. B., Spero, T. L., Wong, D. C., and Young, J. O.: Description and evaluation of the Community Multiscale Air Quality (CMAQ) modeling system version 5.1, Geosci. Model Dev., 10, 1703-1732, https://doi.org/10.5194/gmd-10-1703-2017, 2017.

Atkinson, R. and Arey, J.: Atmospheric degradation of volatile organic compounds, Chem. Rev., 103, 4605-4638, https://doi.org/10.1021/cr0206420, 2003.

Atkinson, R., Baulch, D. L., Cox, R. A., Crowley, J. N., Hampson, R. F., Hynes, R. G., Jenkin, M. E., Rossi, M. J., and Troe, J.: Evaluated kinetic and photochemical data for atmospheric chemistry: Volume $\mathrm{I}-$ gas phase reactions of $\mathrm{O}_{x}, \mathrm{HO}_{x}$, $\mathrm{NO}_{x}$ and $\mathrm{SO}_{x}$ species, Atmos. Chem. Phys., 4, 1461-1738, https://doi.org/10.5194/acp-4-1461-2004, 2004.

Calvert, J. G., Atkinson, R., Becker, K. H., Kamens, R. M., Seinfeld, J. H., Wallington, T. J., and Yarwood, G.: The mechanisms of atmospheric oxidation of aromatic hydrocarbons, Oxford University Press, New York, USA, 2002.

Cao, G. and Jang, M.: Effects of particle acidity and UV light on secondary organic aerosol formation from oxidation of aromatics in the absence of $\mathrm{NO}_{x}$, Atmos. Environ., 41, 7603-7613, https://doi.org/10.1016/j.atmosenv.2007.05.034, 2007.

Carlton, A. G., Pinder, R. W., Bhave, P. V., and Pouliot, G. A.: To what extent can biogenic SOA be controlled? Environ. Sci. Technol., 44, 3376-3380, 2010.

Charron, A., Polo-Rehn, L., Besombes, J.-L., Golly, B., Buisson, C., Chanut, H., Marchand, N., Guillaud, G., and Jaffrezo, J.-L.: Identification and quantification of particulate tracers of exhaust and non-exhaust vehicle emissions, Atmos. Chem. Phys., 19, 51875207, https://doi.org/10.5194/acp-19-5187-2019, 2019.

Chen, Q., Ikemori, F., and Mochida, M.: Light absorption and excitation-emission fluorescence of urban organic aerosol components and their relationship to chemi- cal structure, Environ. Sci. Technol., 50, 10859-10868, https://doi.org/10.1021/acs.est.6b02541, 2016.

Chen, T., Liu, Y., Ma, Q., Chu, B., Zhang, P., Liu, C., Liu, J., and He, H.: Significant source of secondary aerosol: formation from gasoline evaporative emissions in the presence of $\mathrm{SO}_{2}$ and $\mathrm{NH}_{3}$, Atmos. Chem. Phys., 19, 8063-8081, https://doi.org/10.5194/acp-19-8063-2019, 2019.

Chen, T., Xue, L., Zheng, P., Zhang, Y., Liu, Y., Sun, J., Han, G., Li, H., Zhang, X., Li, Y., Li, H., Dong, C., Xu, F., Zhang, Q., and Wang, W.: Volatile organic compounds and ozone air pollution in an oil production region in northern China, Atmos. Chem. Phys., 20, 7069-7086, https://doi.org/10.5194/acp20-7069-2020, 2020.

de Gouw, J. A., Middlebrook, A. M., Warneke, C., Goldan, P. D., Kuster, W. C., Roberts, J. M., Fehsenfeld, F. C., Worsnop, D. R., Canagaratna, M. R., Pszenny, A. A. P., Keene, W. C., Marchewka, M., Bertman, S. B., and Bates, T. S.: Budget of organic carbon in a polluted atmosphere: Results from the New England Air Quality Study in 2002, J. Geophys. Res.-Atmos., 110, D16305, https://doi.org/10.1029/2004jd005623, 2005.

Fahnestock, K. A. S., Yee, L. D., Loza, C. L., Coggon, M. M., Schwantes, R., Zhang, X., Dalleska, N. F., and Seinfeld, J. H.: Secondary Organic Aerosol Composition from $C_{12}$ Alkanes, J. Phys. Chem. A, 119, 4281-4297, https://doi.org/10.1021/jp501779w, 2015.

Galloway, M. M., Loza, C. L., Chhabra, P. S., Chan, A. W. H., Yee, L. D., Seinfeld, J. H., and Keutsch, F. N.: Analysis of photochemical and dark glyoxal uptake: Implications for SOA formation, Geophys. Res. Lett., 38, L17811, https://doi.org/10.1029/2011gl048514, 2011.

Garmash, O., Rissanen, M. P., Pullinen, I., Schmitt, S., Kausiala, O., Tillmann, R., Zhao, D., Percival, C., Bannan, T. J., Priestley, M., Hallquist, A. M., Kleist, E., Kiendler-Scharr, A., Hallquist, M., Berndt, T., McFiggans, G., Wildt, J., Mentel, T. F., and Ehn, M.: Multi-generation $\mathrm{OH}$ oxidation as a source for highly oxygenated organic molecules from aromatics, Atmos. Chem. Phys., 20, 515-537, https://doi.org/10.5194/acp-20-515-2020, 2020.

Gentner, D. R., Isaacman, G., Worton, D. R., Chan, A. W. H., Dallmann, T. R., Davis, L., Liu, S., Day, D. A., Russell, L. M., Wilson, K. R., Weber, R., Guha, A., Harley, R. A., and Goldstein, A. H.: Elucidating secondary organic aerosol from diesel and gasoline vehicles through detailed characterization of organic carbon emissions, P. Natl. Acad. Sci. USA, 109, 18318-18323, https://doi.org/10.1073/pnas.1212272109, 2012.

Glasius, M., la Cour, A., and Lohse, C.: Fossil and nonfossil carbon in fine particulate matter: A study of five European cities, J. Geophys. Res.-Atmos., 116, D11302, https://doi.org/10.1029/2011jd015646, 2011.

Grosjean, D.: ERT outdoor environmental chamber and dedicated analytical facilities, Environ. Res. Technol. Inc., Westlake Village, California, USA, Report P-A704-050, 1981.

Heald, C. L., Jacob, D. J., Park, R. J., Russell, L. M., Huebert, B. J., Seinfeld, J. H., Liao, H., and Weber, R. J.: A large organic aerosol source in the free troposphere missing from current models, Geophys. Res. Lett., 32, L18809, https://doi.org/10.1029/2005g1023831, 2005.

Herrmann, H., Schaefer, T., Tilgner, A., Styler, S. A., Weller, C., Teich, M., and Otto, T.: Tropospheric aqueousphase chemistry: kinetics, mechanisms, and its coupling 
to a changing gas phase, Chem. Rev., 115, 4259-4334, https://doi.org/10.1021/cr500447k, 2015.

Hodzic, A., Jimenez, J. L., Madronich, S., Canagaratna, M. R., DeCarlo, P. F., Kleinman, L., and Fast, J.: Modeling organic aerosols in a megacity: potential contribution of semi-volatile and intermediate volatility primary organic compounds to secondary organic aerosol formation, Atmos. Chem. Phys., 10, 5491-5514, https://doi.org/10.5194/acp-10-5491-2010, 2010.

Hoyle, C. R., Boy, M., Donahue, N. M., Fry, J. L., Glasius, M., Guenther, A., Hallar, A. G., Huff Hartz, K., Petters, M. D., Petäjä, T., Rosenoern, T., and Sullivan, A. P.: A review of the anthropogenic influence on biogenic secondary organic aerosol, Atmos. Chem. Phys., 11, 321-343, https://doi.org/10.5194/acp-11-3212011, 2011.

Huang, J., McQueen, J., Wilczak, J., Djalalova, I., Stajner, I., Shafran, P., Allured, D., Lee, P., Pan, L., Tong, D., Huang, H.-C., DiMego, G., Upadhayay, S., and Delle Monache, L.: Improving NOAA NAQFC $\mathrm{PM}_{2.5}$ Predictions with a Bias Correction Approach, Weather Forecast., 32, 407-421, https://doi.org/10.1175/waf-d-16-0118.1, 2017.

Huang, M., Lin, Y., Huang, X., Liu, X., Guo, X., Hu, C., Zhao, W., Gu, X., Fang, L., and Zhang, W.: Experimental study of particulate products for aging of 1,3,5-trimethylbenzene secondary organic aerosol, Atmos. Pollut. Res., 6, 209-219, https://doi.org/10.5094/apr.2015.025, 2015.

Huang, M., Hao, L., Cai, S., Gu, X., Zhang, W., Hu, C., Wang, Z., Fang, L., and Zhang, W.: Effects of inorganic seed aerosols on the particulate products of aged 1,3,5-trimethylbenzene secondary organic aerosol, Atmos. Environ., 152, 490-502, https://doi.org/10.1016/j.atmosenv.2017.01.010, 2017a.

Huang, M., Xu, J., Cai, S., Liu, X., Hu, C., Gu, X., Fang, L., and Zhang, W.: Mass Spectral Analysis of the Aged 1,3,5Trimethylbenzene Secondary Organic Aerosol in the Presence of Ammonium Sulfate Seeds, Pol. J. Environ. Stud., 26, 15311537, https://doi.org/10.15244/pjoes/66768, 2017 b.

Huang, M., Xu, J., Cai, S., Liu, X., Hu, C., Gu, X., Zhao, W., Fang, L., and Zhang, W.: Chemical analysis of particulate products of aged 1,3,5-trimethylbenzene secondary organic aerosol in the presence of ammonia, Atmos. Pollut. Res., 9, 146-155, https://doi.org/10.1016/j.apr.2017.08.003, 2018.

Huang, X.-G., Shao, T.-J., Zhao, J.-B., Cao, J.-J., and Yue, D.-P.: Impact of meteorological factors and precursors on spatial distribution of ozone concentration in Eastern China, China Environ. Sci., 39, 2273-2282, https://doi.org/10.19674/j.cnki.issn10006923.2019.0270, 2019.

Jaffe, D. A. and Zhang, L.: Meteorological anomalies lead to elevated $\mathrm{O}_{3}$ in the western U.S. in June 2015, Geophys. Res. Lett., 44, 1990-1997, https://doi.org/10.1002/2016g1072010, 2017.

Johnson, D., Jenkin, M. E., Wirtz, K., and Martin-Reviejo, M.: Simulating the formation of secondary organic aerosol from the photooxidation of toluene, Environ. Chem., 1, 150-165, https://doi.org/10.1071/en04069, 2004.

Kanakidou, M., Seinfeld, J. H., Pandis, S. N., Barnes, I., Dentener, F. J., Facchini, M. C., Van Dingenen, R., Ervens, B., Nenes, A., Nielsen, C. J., Swietlicki, E., Putaud, J. P., Balkanski, Y., Fuzzi, S., Horth, J., Moortgat, G. K., Winterhalter, R., Myhre, C. E. L., Tsigaridis, K., Vignati, E., Stephanou, E. G., and Wilson, J.: Organic aerosol and global climate modelling: a review, Atmos.
Chem. Phys., 5, 1053-1123, https://doi.org/10.5194/acp-5-10532005, 2005.

Kansal, A.: Sources and reactivity of NMHCs and VOCs in the atmosphere: a review, J. Hazard. Mater., 166, 17-26, https://doi.org/10.1016/j.jhazmat.2008.11.048, 2009.

Kari, E., Hao, L., Ylisirniö, A., Buchholz, A., Leskinen, A., YliPirilä, P., Nuutinen, I., Kuuspalo, K., Jokiniemi, J., Faiola, C. L., Schobesberger, S., and Virtanen, A.: Potential dual effect of anthropogenic emissions on the formation of biogenic secondary organic aerosol (BSOA), Atmos. Chem. Phys., 19, 15651-15671, https://doi.org/10.5194/acp-19-15651-2019, 2019.

Kelly, J. M., Doherty, R. M., O'Connor, F. M., and Mann, G. W.: The impact of biogenic, anthropogenic, and biomass burning volatile organic compound emissions on regional and seasonal variations in secondary organic aerosol, Atmos. Chem. Phys., 18, 7393-7422, https://doi.org/10.5194/acp-18-7393-2018, 2018.

Kim, H. and Paulson, S. E.: Real refractive indices and volatility of secondary organic aerosol generated from photooxidation and ozonolysis of limonene, $\alpha$-pinene and toluene, Atmos. Chem. Phys., 13, 7711-7723, https://doi.org/10.5194/acp13-7711-2013, 2013.

Kroll, J. H., Chan, A. W. H., Ng, N. L., Flagan, R. C., and Seinfeld, J. H.: Reactions of semivolatile organics and their effects on secondary organic aerosol formation, Environ. Sci. Technol., 41, 3545-3550, 2007.

Laskin, A., Laskin, J., and Nizkorodov, S. A.: Chemistry of atmospheric brown carbon, Chem. Rev., 115, 4335-4382, https://doi.org/10.1021/cr5006167, 2015.

Lauraguais, A., Coeur-Tourneur, C., Cassez, A., and Seydi, A.: Rate constant and secondary organic aerosol yields for the gas-phase reaction of hydroxyl radicals with syringol (2,6-dimethoxyphenol), Atmos. Environ., 55, 43-48, https://doi.org/10.1016/j.atmosenv.2012.02.027, 2012.

Lauraguais, A., Coeur-Tourneur, C., Cassez, A., Deboudt, K., Fourmentin, M., and Choël, M.: Atmospheric reactivity of hydroxyl radicals with guaiacol (2-methoxyphenol), a biomass burning emitted compound: Secondary organic aerosol formation and gas-phase oxidation products, Atmos. Environ., 86, 155-163, https://doi.org/10.1016/j.atmosenv.2013.11.074, 2014.

Li, J., Li, K., Wang, W., Wang, J., Peng, C., and Ge, M.: Optical properties of secondary organic aerosols derived from long-chain alkanes under various $\mathrm{NO}_{x}$ and seed conditions, Sci. Total Environ., 579, 1699-1705, https://doi.org/10.1016/j.scitotenv.2016.11.189, 2017.

Li, J., Wang, W., Li, K., Zhang, W., Peng, C., Zhou, L., Shi, B., Chen, Y., Liu, M., Li, H., and Ge, M.: Temperature effects on optical properties and chemical composition of secondary organic aerosol derived from $n$-dodecane, Atmos. Chem. Phys., 20, 8123-8137, https://doi.org/10.5194/acp-20-8123-2020, 2020.

Li, J., Li, H., Wang, X., Wang, W., Ge, M., Zhang, H., Zhang, X., Li, K., Chen, Y., Wu, Z., Chai, F., Meng, F., Mu, Y., Mellouki, A., Bi, F., Zhang, Y., Wu, L., and Liu, Y.: A large-scale outdoor atmospheric simulation smog chamber for studying atmospheric photochemical processes: Characterization and preliminary application, J. Environ. Sci., 102, 185-197, 2021.

Li, K., Li, J., Liggio, J., Wang, W., Ge, M., Liu, Q., Guo, Y., Tong, S., Li, J., Peng, C., Jing, B., Wang, D., and Fu, P.: Enhanced light scattering of secondary organic aerosols by 
multiphase reactions, Environ. Sci. Technol., 51, 1285-1292, https://doi.org/10.1021/acs.est.6b03229, 2017a.

Li, K., Li, J., Wang, W., Tong, S., Liggio, J., and Ge, M.: Evaluating the effectiveness of joint emission control policies on the reduction of ambient VOCs: Implications from observation during the 2014 APEC summit in suburban Beijing, Atmos. Environ., 164, 117-127, https://doi.org/10.1016/j.atmosenv.2017.05.050, $2017 b$.

Li, K., Li, J., Wang, W., Li, J., Peng, C., Wang, D., and Ge, M.: Effects of gas-particle partitioning on refractive index and chemical composition of $m$-xylene secondary organic aerosol, J. Phys. Chem. A, 122, 3250-3260, https://doi.org/10.1021/acs.jpca.7b12792, 2018.

Lim, Y. B. and Ziemann, P. J.: Products and mechanism of secondary organic aerosol formation from reactions of $n$-alkanes with $\mathrm{OH}$ radicals in the presence of $\mathrm{NO}_{x}$, Environ. Sci. Technol., 39, 9229-9236, https://doi.org/10.1021/es051447g, 2005.

Lim, Y. B. and Ziemann, P. J.: Effects of molecular structure on aerosol yields from $\mathrm{OH}$ radical-initiated reactions of linear, branched, and cyclic alkanes in the presence of $\mathrm{NO}_{x}$, Environ. Sci. Technol., 43, 2328-2334, https://doi.org/10.1021/es803389s, 2009.

Loza, C. L., Craven, J. S., Yee, L. D., Coggon, M. M., Schwantes, R. H., Shiraiwa, M., Zhang, X., Schilling, K. A., Ng, N. L., Canagaratna, M. R., Ziemann, P. J., Flagan, R. C., and Seinfeld, J. H.: Secondary organic aerosol yields of 12-carbon alkanes, Atmos. Chem. Phys., 14, 1423-1439, https://doi.org/10.5194/acp14-1423-2014, 2014.

Luo, H., Jia, L., Wan, Q., An, T., and Wang, Y.: Role of liquid water in the formation of $\mathrm{O}_{3}$ and SOA particles from 1,2,3-trimethylbenzene, Atmos. Environ., 217, 116955, https://doi.org/10.1016/j.atmosenv.2019.116955, 2019.

McFiggans, G., Mentel, T. F., Wildt, J., Pullinen, I., Kang, S., Kleist, E., Schmitt, S., Springer, M., Tillmann, R., Wu, C., Zhao, D., Hallquist, M., Faxon, C., Le Breton, M., Hallquist, A. M., Simpson, D., Bergstrom, R., Jenkin, M. E., Ehn, M., Thornton, J. A., Alfarra, M. R., Bannan, T. J., Percival, C. J., Priestley, M., Topping, D., and Kiendler-Scharr, A.: Secondary organic aerosol reduced by mixture of atmospheric vapours, Nature, 565, 587-593, https://doi.org/10.1038/s41586-018-0871-y, 2019.

McMurry, P. H. and Grosjean, D.: Gas and aerosol wall losses in Teflon film smog chambers, Environ. Sci. Technol., 19, 11761182, https://doi.org/10.1021/es00142a006, 1985.

Mellouki, A., Wallington, T. J., and Chen, J.: Atmospheric chemistry of oxygenated volatile organic compounds: impacts on air quality and climate, Chem. Rev., 115, 3984-4014, https://doi.org/10.1021/cr500549n, 2015.

Midey, A. J., Williams, S., Miller, T. M., and Viggiano, A. A.: Reactions of $\mathrm{O}_{2}^{+}, \mathrm{NO}^{+}$and $\mathrm{H}_{3} \mathrm{O}^{+}$with methylcyclohexane $\left(\mathrm{C}_{7} \mathrm{H}_{14}\right)$ and cyclooctane $\left(\mathrm{C}_{8} \mathrm{H}_{16}\right)$ from 298 to $700 \mathrm{~K}$, Int. J. Mass Spectrom., 222, 413-430, 2003.

Moise, T., Flores, J. M., and Rudich, Y.: Optical properties of secondary organic aerosols and their changes by chemical processes, Chem. Rev., 115, 4400-4439, https://doi.org/10.1021/cr5005259, 2015.

Nakao, S., Tang, P., Tang, X., Clark, C. H., Qi, L., Seo, E., Asa-Awuku, A., and Cocker, D.: Density and elemental ratios of secondary organic aerosol: Application of a density prediction method, Atmos. Environ., 68, 273-277, https://doi.org/10.1016/j.atmosenv.2012.11.006, 2013.

Ng, N. L., Chhabra, P. S., Chan, A. W. H., Surratt, J. D., Kroll, J. H., Kwan, A. J., McCabe, D. C., Wennberg, P. O., Sorooshian, A., Murphy, S. M., Dalleska, N. F., Flagan, R. C., and Seinfeld, J. H.: Effect of $\mathrm{NO}_{x}$ level on secondary organic aerosol (SOA) formation from the photooxidation of terpenes, Atmos. Chem. Phys. 7, 5159-5174, https://doi.org/10.5194/acp-7-5159-2007, 2007a.

Ng, N. L., Kroll, J. H., Chan, A. W. H., Chhabra, P. S., Flagan, R. C., and Seinfeld, J. H.: Secondary organic aerosol formation from $m$-xylene, toluene, and benzene, Atmos. Chem. Phys., 7, 3909-3922, https://doi.org/10.5194/acp-7-3909-2007, 2007b.

Odum, J. R., Hoffmann, T., Bowman, F., Collins, D., Flagan, R. C., and Seinfeld, J. H.: Gas/particle partitioning and secondary organic aerosol yields, Environ. Sci. Technol., 30, 2580-2585, https://doi.org/10.1021/es950943+, 1996.

Paulsen, D., Dommen, J., Kalberer, M., Prevot, A. S. H., Richter, R., Sax, M., Steinbacher, M., Weingartner, E., and Baltensperger, U.: Secondary organic aerosol formation by irradiation of 1,3,5trimethylbenzene- $\mathrm{NO}_{x}-\mathrm{H}_{2} \mathrm{O}$ in a new reaction chamber for atmospheric chemistry and physics, Environ. Sci. Technol., 39, 2668-2678, 2005.

Phillips, S. M. and Smith, G. D.: Light absorption by charge transfer complexes in brown carbon aerosols, Environ. Sci. Tech. Let., 1, 382-386, https://doi.org/10.1021/ez500263j, 2014.

Poschl, U.: Atmospheric aerosols: Composition, transformation, climate and health effects, Angew. Chem. Int. Edit., 44, 7520 7540, https://doi.org/10.1002/anie.200501122, 2005.

Poschl, U. and Shiraiwa, M.: Multiphase chemistry at the atmosphere-biosphere interface influencing climate and public health in the anthropocene, Chem. Rev., 115, 4440-4475, https://doi.org/10.1021/cr500487s, 2015.

Ren, J., Zhang, F., Wang, Y., Collins, D., Fan, X., Jin, X., Xu, W., Sun, Y., Cribb, M., and Li, Z.: Using different assumptions of aerosol mixing state and chemical composition to predict $\mathrm{CCN}$ concentrations based on field measurements in urban Beijing, Atmos. Chem. Phys., 18, 6907-6921, https://doi.org/10.5194/acp18-6907-2018, 2018.

Requia, W. J., Higgins, C. D., Adams, M. D., Mohamed, M., and Koutrakis, P.: The health impacts of weekday traffic: A health risk assessment of $\mathrm{PM}_{2.5}$ emissions during congested periods, Environ. Int., 111, 164-176, https://doi.org/10.1016/j.envint.2017.11.025, 2018.

Robinson, A. L., Donahue, N. M., Shrivastava, M. K., Weitkamp, E. A., Sage, A. M., Grieshop, A. P., Lane, T. E., Pierce, J. R., and Pandis, S. N.: Rethinking organic aerosols: Semivolatile emissions and photochemical aging, Science, 315, 1259-1262, https://doi.org/10.1126/science.1133061, 2007.

Saathoff, H., Naumann, K.-H., Möhler, O., Jonsson, Å. M., Hallquist, M., Kiendler-Scharr, A., Mentel, Th. F., Tillmann, R., and Schurath, U.: Temperature dependence of yields of secondary organic aerosols from the ozonolysis of $\alpha$-pinene and limonene, Atmos. Chem. Phys., 9, 1551-1577, https://doi.org/10.5194/acp9-1551-2009, 2009.

Sato, K., Fujitani, Y., Inomata, S., Morino, Y., Tanabe, K., Hikida, T., Shimono, A., Takami, A., Fushimi, A., Kondo, Y., Imamura, T., Tanimoto, H., and Sugata, S.: A study of volatility by composition, heating, and dilution measurements of secondary organic aerosol from 1,3,5-trimethylbenzene, Atmos. 
Chem. Phys., 19, 14901-14915, https://doi.org/10.5194/acp-1914901-2019, 2019.

Schauer, J. J., Kleeman, M. J., Cass, G. R., and Simoneit, B. R. T.: Measurement of emissions from air pollution sources, 5. $\mathrm{C}_{1}-\mathrm{C}_{32}$ organic compounds from gasolinepowered motor vehicles, Environ. Sci. Technol., 36, 1169-1180, https://doi.org/10.1021/es0108077, 2002.

Seinfeld, J. H. and Pandis, S. N.: Atmospheric chemistry and physics: from air pollution to climate change, 3rd edn., John Wiley \& Sons, Hoboken, 2016.

Shilling, J. E., Zaveri, R. A., Fast, J. D., Kleinman, L., Alexander, M. L., Canagaratna, M. R., Fortner, E., Hubbe, J. M., Jayne, J. T., Sedlacek, A., Setyan, A., Springston, S., Worsnop, D. R., and Zhang, Q.: Enhanced SOA formation from mixed anthropogenic and biogenic emissions during the CARES campaign, Atmos. Chem. Phys., 13, 2091-2113, https://doi.org/10.5194/acp-132091-2013, 2013.

Shiraiwa, M., Yee, L. D., Schilling, K. A., Loza, C. L., Craven, J. S., Zuend, A., Ziemann, P. J., and Seinfeld, J. H.: Size distribution dynamics reveal particle-phase chemistry in organic aerosol formation, P. Natl. Acad. Sci. USA, 110, 11746-11750, https://doi.org/10.1073/pnas.1307501110, 2013.

Shrivastava, M., Cappa, C. D., Fan, J., Goldstein, A. H., Guenther, A. B., Jimenez, J. L., Kuang, C., Laskin, A., Martin, S. T., Ng, N. L., Petaja, T., Pierce, J. R., Rasch, P. J., Roldin, P., Seinfeld, J. H., Shilling, J., Smith, J. N., Thornton, J. A., Volkamer, R., Wang, J., Worsnop, D. R., Zaveri, R. A., Zelenyuk, A., and Zhang, Q.: Recent advances in understanding secondary organic aerosol: Implications for global climate forcing, Rev. Geophys., 55, 509559, https://doi.org/10.1002/2016rg000540, 2017.

Slowik, J. G., Stroud, C., Bottenheim, J. W., Brickell, P. C., Chang, R. Y.-W., Liggio, J., Makar, P. A., Martin, R. V., Moran, M. D., Shantz, N. C., Sjostedt, S. J., van Donkelaar, A., Vlasenko, A., Wiebe, H. A., Xia, A. G., Zhang, J., Leaitch, W. R., and Abbatt, J. P. D.: Characterization of a large biogenic secondary organic aerosol event from eastern Canadian forests, Atmos. Chem. Phys., 10, 2825-2845, https://doi.org/10.5194/acp-102825-2010, 2010.

Spracklen, D. V., Jimenez, J. L., Carslaw, K. S., Worsnop, D. R., Evans, M. J., Mann, G. W., Zhang, Q., Canagaratna, M. R., Allan, J., Coe, H., McFiggans, G., Rap, A., and Forster, P.: Aerosol mass spectrometer constraint on the global secondary organic aerosol budget, Atmos. Chem. Phys., 11, 12109-12136, https://doi.org/10.5194/acp-11-12109-2011, 2011.

Tkacik, D. S., Presto, A. A., Donahue, N. M., and Robinson, A. L.: Secondary Organic Aerosol Formation from Intermediate-Volatility Organic Compounds: Cyclic, Linear, and Branched Alkanes, Environ. Sci. Technol., 46, 8773-8781, https://doi.org/10.1021/es301112c, 2012.

Trostl, J., Chuang, W. K., Gordon, H., Heinritzi, M., Yan, C., Molteni, U., Ahlm, L., Frege, C., Bianchi, F., Wagner, R., Simon, M., Lehtipalo, K., Williamson, C., Craven, J. S., Duplissy, J., Adamov, A., Almeida, J., Bernhammer, A. K., Breitenlechner, M., Brilke, S., Dias, A., Ehrhart, S., Flagan, R. C., Franchin, A., Fuchs, C., Guida, R., Gysel, M., Hansel, A., Hoyle, C. R., Jokinen, T., Junninen, H., Kangasluoma, J., Keskinen, H., Kim, J., Krapf, M., Kurten, A., Laaksonen, A., Lawler, M., Leiminger, M., Mathot, S., Mohler, O., Nieminen, T., Onnela, A., Petaja, T., Piel, F. M., Miettinen, P., Rissanen, M. P.,
Rondo, L., Sarnela, N., Schobesberger, S., Sengupta, K., Sipila, M., Smith, J. N., Steiner, G., Tome, A., Virtanen, A., Wagner, A. C., Weingartner, E., Wimmer, D., Winkler, P. M., Ye, P., Carslaw, K. S., Curtius, J., Dommen, J., Kirkby, J., Kulmala, M., Riipinen, I., Worsnop, D. R., Donahue, N. M., and Baltensperger, U.: The role of low-volatility organic compounds in initial particle growth in the atmosphere, Nature, 533, 527-531, https://doi.org/10.1038/nature18271, 2016.

Tsiligiannis, E., Hammes, J., Salvador, C. M., Mentel, T. F., and Hallquist, M.: Effect of $\mathrm{NO}_{x}$ on 1,3,5-trimethylbenzene (TMB) oxidation product distribution and particle formation, Atmos. Chem. Phys., 19, 15073-15086, https://doi.org/10.5194/acp-1915073-2019, 2019.

Volkamer, R., Jimenez, J. L., San Martini, F., Dzepina, K., Zhang, Q., Salcedo, D., Molina, L. T., Worsnop, D. R., and Molina, M. J.: Secondary organic aerosol formation from anthropogenic air pollution: Rapid and higher than expected, Geophys. Res. Lett., 33, L17811, https://doi.org/10.1029/2006g1026899, 2006.

von Schneidemesser, E., Monks, P. S., Allan, J. D., Bruhwiler, L., Forster, P., Fowler, D., Lauer, A., Morgan, W. T., Paasonen, P., Righi, M., Sindelarova, K., and Sutton, M. A.: Chemistry and the Linkages between Air Quality and Climate Change, Chem. Rev., 115, 3856-3897, https://doi.org/10.1021/acs.chemrev.5b00089, 2015.

Wang, C., Yuan, B., Wu, C., Wang, S., Qi, J., Wang, B., Wang, Z., Hu, W., Chen, W., Ye, C., Wang, W., Sun, Y., Wang, C., Huang, S., Song, W., Wang, X., Yang, S., Zhang, S., Xu, W., Ma, N., Zhang, Z., Jiang, B., Su, H., Cheng, Y., Wang, X., and Shao, M.: Measurements of higher alkanes using $\mathrm{NO}^{+}$chemical ionization in PTR-ToF-MS: important contributions of higher alkanes to secondary organic aerosols in China, Atmos. Chem. Phys., 20, 14123-14138, https://doi.org/10.5194/acp-20-141232020, 2020.

Wang, T., Xue, L., Brimblecombe, P., Lam, Y. F., Li, L., and Zhang, L.: Ozone pollution in China: A review of concentrations, meteorological influences, chemical precursors, and effects, Sci. Total Environ., 575, 1582-1596, https://doi.org/10.1016/j.scitotenv.2016.10.081, 2017.

Wirtz, K. and Martin-Reviejo, M.: Density of secondary organic aerosols, J. Aerosol Sci., 34, 223-224, 2003.

$\mathrm{Wu}$, R. and Xie, S.: Spatial Distribution of secondary organic aerosol formation potential in China derived from speciated anthropogenic volatile organic compound emissions, Environ. Sci. Technol., 52, 8146-8156, https://doi.org/10.1021/acs.est.8b01269, 2018.

Yang, J. C., Roth, P., Durbin, T. D., Johnson, K. C., Cocker III, D. R., Asa-Awuku, A., Brezny, R., Geller, M., and Karavalakis, G.: Gasoline Particulate Filters as an Effective Tool to Reduce Particulate and Polycyclic Aromatic Hydrocarbon Emissions from Gasoline Direct Injection (GDI) Vehicles: A Case Study with Two GDI Vehicles, Environ. Sci. Technol., 52, 32753284, https://doi.org/10.1021/acs.est.7b05641, 2018.

Yee, L. D., Craven, J. S., Loza, C. L., Schilling, K. A., Ng, N. L., Canagaratna, M. R., Ziemann, P. J., Flagan, R. C., and Seinfeld, J. H.: Secondary organic aerosol formation from low- $\mathrm{NO}_{x}$ photooxidation of dodecane: evolution of multigeneration gasphase chemistry and aerosol composition, J. Phys. Chem. A, 116, 6211-6230, https://doi.org/10.1021/jp211531h, 2012. 
Yee, L. D., Craven, J. S., Loza, C. L., Schilling, K. A., Ng, N. L., Canagaratna, M. R., Ziemann, P. J., Flagan, R. C., and Seinfeld, J. H.: Effect of chemical structure on secondary organic aerosol formation from $\mathrm{C}_{12}$ alkanes, Atmos. Chem. Phys., 13, 1112111140, https://doi.org/10.5194/acp-13-11121-2013, 2013.

Zhang, H., Wang, S., Hao, J., Wang, X., Wang, S., Chai, F., and Li, M.: Air pollution and control action in Beijing, J. Clean. Prod., 112, 1519-1527, https://doi.org/10.1016/j.jclepro.2015.04.092, 2016.

Zhang, R., Wang, G., Guo, S., Zamora, M. L., Ying, Q., Lin, Y., Wang, W., Hu, M., and Wang, Y.: Formation of urban fine particulate matter, Chem. Rev., 115, 3803-3855, https://doi.org/10.1021/acs.chemrev.5b00067, 2015.

Zhang, X., Cappa, C. D., Jathar, S. H., McVay, R. C., Ensberg, J. J., Kleeman, M. J., and Seinfeld, J. H.: Influence of vapor wall loss in laboratory chambers on yields of secondary organic aerosol, $\mathrm{P}$. Natl. Acad. Sci. USA, 111, 5802-5807, 2014.

Zhang, X., Schwantes, R. H., McVay, R. C., Lignell, H., Coggon, M. M., Flagan, R. C., and Seinfeld, J. H.: Vapor wall deposition in Teflon chambers, Atmos. Chem. Phys., 15, 4197-4214, https://doi.org/10.5194/acp-15-4197-2015, 2015.
Zhao, B., Wang, S., Donahue, N. M., Jathar, S. H., Huang, X., Wu, W., Hao, J., and Robinson, A. L.: Quantifying the effect of organic aerosol aging and intermediate-volatility emissions on regional-scale aerosol pollution in China, Sci. Rep.-UK, 6, 28815, https://doi.org/10.1038/srep28815, 2016.

Zhao, Y., Nguyen, N. T., Presto, A. A., Hennigan, C. J., May, A. A., and Robinson, A. L.: Intermediate volatility organic compound emissions from on-road diesel vehicles: Chemical composition, emission factors, and estimated secondary organic aerosol production, Environ. Sci. Technol., 49, 11516-11526, https://doi.org/10.1021/acs.est.5b02841, 2015.

Zhou, Y., Zhang, H., Parikh, H. M., Chen, E. H., Rattanavaraha, W., Rosen, E. P., Wang, W., and Kamens, R. M.: Secondary organic aerosol formation from xylenes and mixtures of toluene and xylenes in an atmospheric urban hydrocarbon mixture: Water and particle seed effects (II), Atmos. Environ., 45, 3882-3890, https://doi.org/10.1016/j.atmosenv.2010.12.048, 2011. 